\title{
International Journal of Accounting Information Systems
}

\section{Extent of managerial IT use, learning routines, and firm performance: A structural equation modeling of their relationship}

\author{
Adam S. Maiga ${ }^{\mathrm{a}, 1}$, Anders Nilsson ${ }^{\mathrm{b}, *}$, Fred A. Jacobs ${ }^{\mathrm{c}, 2}$ \\ a School of Accounting, Florida International University, University Park, 11200 SW 8th Street, Miami, FL 33199, United States \\ b Department of Business Administration, Technology and Social Sciences, Luleå University of Technology, Luleå, SE 97187, Sweden \\ ' School of Accountancy, Georgia State University, 35 Broad Street, 5th Floor, Atlanta, GA 30302-4050, United States
}

\section{A R T I C L E I N F O}

\section{Article history:}

Received 16 December 2010

Received in revised form 26 March 2013

Accepted 23 April 2013

Available online $\mathrm{xxxx}$

\section{Keywords:}

Managerial IT use

Control

Learning routines

Product quality

Cost improvement

Customer satisfaction

Firm profitability

Structural equation modeling

\begin{abstract}
A B S T R A C T
Organizations increasingly rely on information technology (IT) to improve performance. Yet, there is debate about the pay-off of the IT revolution, and empirical evidence suggests that investments in IT do not guarantee enhanced performance. Drawing from accounting, marketing, management and information technology literature, this study uses structural equation modeling to assess the extent to which managerial use of IT is intertwined with control issues including learning routines (internal and external), product quality, cost improvement, customer satisfaction and firm profitability. The conceptual framework builds on knowledge- and resource-based views and return on quality perspectives. The results indicate support for the theoretical framework. Extent of managerial IT use influences internal and external learning routines that influence quality and cost improvement. Quality improvement significantly impacts customer satisfaction and cost improvement that significantly impact firm profitability. The non-hypothesized paths are not significant, indicating that learning routines, quality improvement, cost improvement and customer satisfaction are intervening variables between extent of managerial IT use and firm profitability. Further, the sample is split into two industry subgroups, durable and nondurable goods subgroups, and the two-group analysis reveals that industry moderates the relationship among the variables under study. The effects are in general more pronounced for durable goods firms.
\end{abstract}

(c) 2013 Elsevier Inc. All rights reserved.

* Corresponding author. Tel.: +46920 491095; fax: + 46920491399.

E-mail addresses: maigaa@fiu.edu (A.S. Maiga), l.e.anders.nilsson@ltu.se (A. Nilsson), fjacobs@gsu.edu (F.A. Jacobs).

1 Tel.: +1 305348 0503; fax: +1 3053482914 .

2 Tel.: +1 770638 8188; fax: +1 4044137203 .

1467-0895/\$ - see front matter @ 2013 Elsevier Inc. All rights reserved.

http://dx.doi.org/10.1016/j.accinf.2013.04.001 


\section{Introduction}

Many companies have invested heavily in information technology (IT) with the hope of enhancing their performance. Although most of the earlier conceptual research tends to support the idea that IT can be used to create a favorable competitive advantage and sustain firm performance (Porter, 1980; Porter and Millar, 1985; Rackoff et al., 1985), empirical evidence shows that IT does not necessarily create a competitive advantage and there is no significant direct connection between IT and performance (e.g., Kettinger et al., 1994; Hitt and Brynjolfsson, 1996; Powell and Dent-Micallef, 1997; Makadok, 2001; Lau et al., 2010). Due to the concerns expressed in these studies about whether IT use will necessarily lead to enhancements in firm performance, several studies have stressed the need for better theoretical models that trace the path from IT to business performance (Beath et al., 1994; Sambamurthy and Zmud, 1994; Kallunki et al., 2011). For example, Barua and Mukhopadhyay (2000) and Sambamurthy et al. (2003) suggest that many studies have overlooked important intermediate organizational capabilities that mediate the relationship between IT and firm performance. Similarly, Tippins and Sohi (2003) suggest that the impact of IT on performance can be enhanced when used to learn about markets and other factors that influence performance. ${ }^{3}$

Prior research suggests that learning plays an important role in enhancing a firm's competitive advantage (Lee et al., 1996; Simonin, 1999). ${ }^{4}$ These suggestions are consistent with the resource-based theory, which suggests that enhanced competitive advantage is caused by the firm's unique resources (Smith et al., 1996). Since the capability to learn is also a valuable resource, creating and sustaining a firm's competitive advantage is considerably dependent on the learning routines of that firm (Little et al., 2002). Therefore, effective learning routines can contribute to the attainment of the organization's competitive advantage and as a result, improve organizational performance. More specifically, well-developed learning routines provide conditions that enable decision-makers to take advantage of new information related to internal and external opportunities and threats. In turn, such information is relevant in formulating strategy to gain competitive advantage in terms of, at least, quality improvement and lower costs (Jelinek, 1979; Hambrick, 1982; Shrivastava, 1983; Dutton and Freedman, 1985). However, Porter (1980) maintains that every firm must choose between improving quality or lowering costs as it is not possible for firms to accomplish both simultaneously and be successful. On the other hand, Hall (1980) observed that most successful firms simultaneously pursued both cost and quality improvements, suggesting that the two strategies are not necessarily inconsistent. However, despite long-standing interest in multidimensional performance management (e.g., Lynch and Cross, 1991; Kaplan and Norton, 1992), no prior study has investigated the effect of internal and external learning routines on both firm cost and quality improvements. Thus, this study conjectures that benefits from managerial IT use may occur through the creation and utilization of learning routines that result in quality and cost improvements. Further, quality improvement is expected to significantly impact customer satisfaction that, in turn, will impact profitability. In addition, cost improvement is expected to significantly affect profitability.

The foregoing suggests a set of questions related to whether the extent of managerial IT use impacts firm performance directly or whether the mechanism includes intervening relationships among other variables. Thus, the first objective of this study is to examine the following simultaneous relationships: (1) the impact of extent of managerial IT use on firm internal and external learning routines, (2) the effects of internal and external learning routines on firm competitive advantage as measured by its cost and quality improvements, (3) the effect of quality improvement on cost improvement and customer satisfaction, and (4) the impact of cost improvement on firm profitability, the effect of customer satisfaction on firm profitability, and the effect of managerial IT use on firm profitability. The inclusion of these mediating components is a potentially important extension to IT research that has previously considered only the direct link between IT and profitability. In addition, the set of relationships tested is intended to illuminate how IT can be mobilized to manage performance (Dechow et al., 2007). Therefore, the joint consideration of learning routines, cost, quality, and customer satisfaction provides a more complete model of the impact of managerial use of IT on firm profitability and contributes to the existing literature by offering insight into the process by which firms control the enhancement of profitability. To this end, as a central intention and contribution of this study, we

\footnotetext{
${ }^{3}$ The actual use of IT to enhance communication should matter rather than the nominal amounts invested in particular technologies (Andersen, 2001).

${ }^{4}$ Young and Selto (1993) found that an information shortage causes many problems in the manufacturing process because of ineffective learning.
} 
develop and test a model that integrates key aspects of management, accounting, marketing, and IT literature and the perspectives on the link between managerial IT use and firm profitability. In addition, we draw on recent refinements concerning methods to model contributors to performance (Maiga and Jacobs, 2005) while considering managerial IT use and learning routines as part of an expanded set of potentially decisive factors.

The remainder of the paper is structured in four sections. The next section presents the definitions of the variables used in this study, the theoretical model and hypotheses development. This is followed by sections that discuss the research method and present results. Finally, conclusions are discussed.

\section{Definitions, theoretical model and hypotheses development}

\subsection{Definitions}

Extent of managerial IT use is defined as the extent to which computer networks are used by management to enhance internal and external communication. This allows managers to communicate within and outside the organization (Andersen, 2001).

Based on prior studies (e.g., Adler and Clark, 1991; Pisano, 1994), we focus on two types of learning routines - internal and external. Internal and external learning are metaroutines that emphasize problem solving and collaboration both internally within the organization (Huang et al., 2008) and outside the firm to be transferred inside the firm and throughout the organization (Cohen and Levinthal, 1990; Lane et al., 2006).

Quality improvement refers to internal quality. It captures the ability of a manufacturing firm to produce products conforming to their designed quality at an economic production cost (Crosby, 1996); thus, our quality measures subsume internal failure costs (Dawson and Patrickson, 1991; Ahire, 1996).

Customer satisfaction relates to the customer's perspective of the products upon actual usage. For example, a lower percentage of defective products should help a firm to reinforce positive customer experience (Hardie, 1998). Therefore, following prior studies (Voss and Blackmon, 1994; Ahire and Dreyfus, 2000; Maiga and Jacobs, 2005), external quality is used as a proxy for customer satisfaction because lower external failure is likely to be associated with higher customer satisfaction.

Cost improvement is defined as the improvement of firm product cost that is a function of direct labor, direct materials, and allocated overhead, plus improvement in non-manufacturing costs. Consequently, most firms have a reasonably accurate understanding of their incurred costs (D'Souza and Williams, 2000).

Profitability is the composite measure of firm's return on sales (ROS), turnover on assets (TOA), and return on assets (ROA).

\subsection{Theoretical model and hypotheses development}

Fig. 1 illustrates the model guiding this study. We elaborate on the constructs in the model and state our hypotheses in the following sections.

\subsubsection{Extent of managerial IT use and learning routines}

There has been renewed interest over the past two decades in the learning organization (Hayes et al., 1988; Stata, 1989; Senge, 1990a,b, 1991; Kochan and Useem, 1992; Quinn Mills and Friesen, 1992; Garvin, 1993). Today, management needs to harness the learning capabilities of their organization members (Lambert and Peppard, 1993). To this end, managers in many organizations have attempted to design learning routines into their IT systems.

Through managerial IT use, members of the organization can connect internally and the organization can connect to its environment (Huber, 1982), thereby enabling internal and external learning (Kessler et al., 2000) through connectivity-enhancing routines (Levitt and March, 1988; Fawcett et al, 2011).

Prior literature suggests that expectations and beliefs about IT tend to influence actual use of such systems (e.g., Bhattacherjee and Premkumar, 2004). Thus, in a firm where top management invests in information technology it might be expected that their attitudes towards IT would be favorable and that the extent of managerial IT use should be high. This is because the characteristics of contemporary IT networks (i.e. their functionalities when it comes to connectivity, information capture and learning support), make it plausible that when management is eager to use IT, they will use such networks to create conditions, environments and 


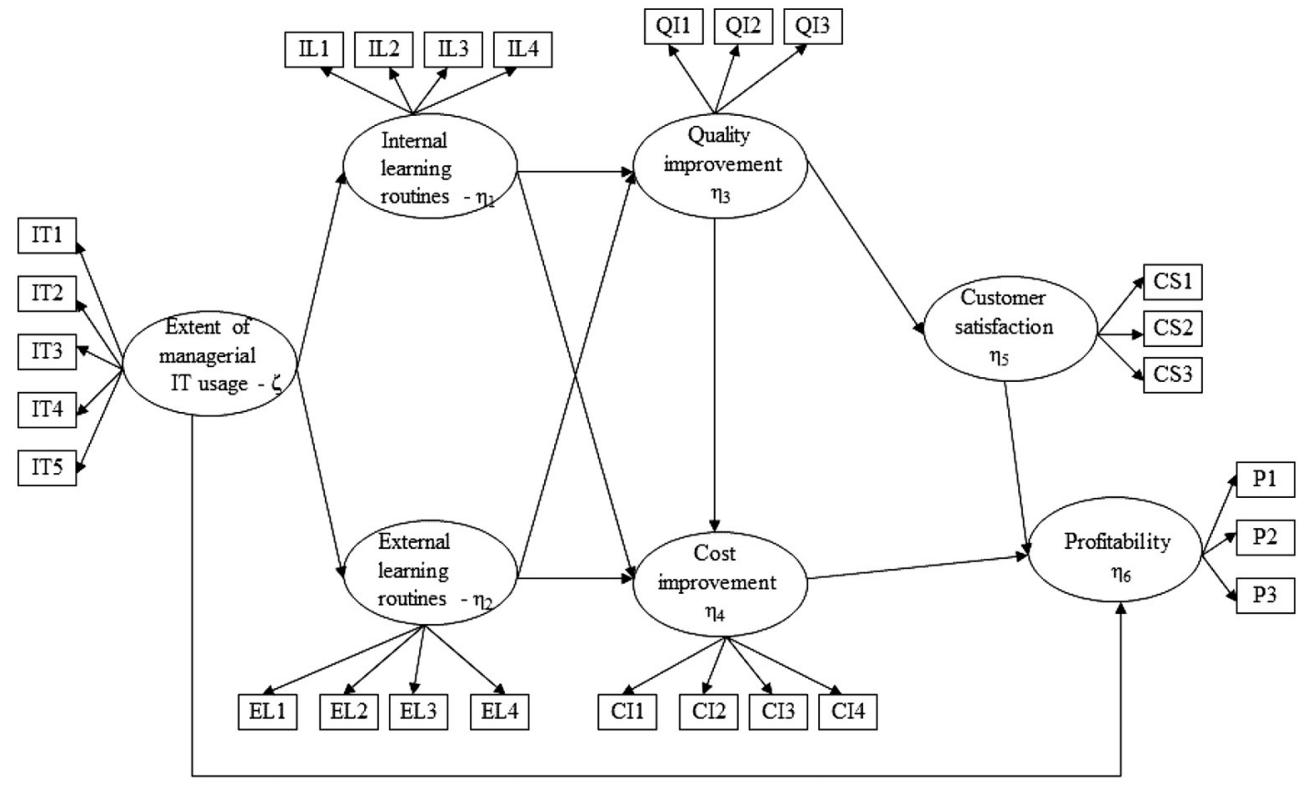

Note: IT1 through IT5, II1 through IL4, EL1 through EL4, OI1 through OI3, CI1 through CI4, CS1 through CS3, and P1 through P3 are items measuring Extent of IT managerial use, Internal learning routines, External learning routines, Quality improvement, Cost improvement, Customer satisfaction, and Profitability respectively.

Fig. 1. Conceptual model.

situations that strengthen the capacity of decision-makers in the firm and externally to detect and exchange new information, and to collaborate in problem solving. The use of IT, with its protocols and platform standards, can provide an ideal mechanism for connecting widely dispersed individuals via common systems (e.g., intranets) (Tippins and Sohi, 2003). That is, the use of IT, such as groupware, facilitates the capture of context-rich information and primarily supports learning activities by providing access to documents, database information, project records, email, and discussion group work areas. A web interface supports learning by providing a gateway to myriad sources and types of information, both internal and external.

This suggests that, in firms where management uses IT extensively, there will be network tools which assist management in clarifying assumptions, speeding up communications, and constructing histories of insights and cataloging them (Sabherwal and King, 1991). That is, managerial use of IT can play a significant role in supporting internal and external learning routines as the firm regularly engages in problem solving in ways that function as routine-changing routines (Nelson and Winter, 1982; Pedler et al., 1997; Teece, 2000).

H1a. There is a positive association between extent of managerial IT use and internal learning routines.

H1b. There is a positive association between extent of managerial IT use and external learning routines.

\subsubsection{Learning routines and competitive advantage}

When internal and external learning routines are in place, there will be occasions for internal and external learning (Lin, 2003). Therefore, learning routines are likely to increase the capacity of individual employees to develop innovative ideas regarding products and processes (Mohrman and Mohrman, 1993; Tippins and Sohi, 2003), which in turn contribute to the organization's competitive advantage (Conner and Prahalad, 1996). More specifically, the implementation of learning routines indicates an organization's commitment to continuous improvement (Garvin, 1993).

Continuous improvement programs involve doing things right the first time and learning best practices in order to improve product quality and reduce costs. Both quality and cost improvements require a solid understanding of underlying processes and products. The existence of internal learning routines makes such understanding possible and gets employees involved in internal problem solving so that they can use their 
insights to identify problem areas and develop effective solutions (Mohrman and Mohrman, 1993; Fawcett et al, 2011). Several studies demonstrate that internal learning routines have positive performance effects (e.g., Bunderson and Sutcliffe, 2003; Gibson and Vermeulen, 2003; Wong, 2004) and point to a number of mechanisms by which performance may be enhanced. Specifically, through internal learning activities, employees are able to detect and correct errors, improve members' collective understanding of a situation, or discover unexpected consequences of previous actions, improving both quality and cost. Based on the foregoing discussions, we propose the following hypotheses linking internal learning routines and quality and cost improvements:

H2a. There is a positive association between internal learning routines and quality improvement.

H2b. There is a positive association between internal learning routines and cost improvement.

Routines for external learning can be integrated into a new product design through blending techniques, such as matching product attributes with needs, and can contribute to new product advantages by enabling a firm to explore innovation opportunities created by emerging market demand (Tiger and Calantone, 1998). Hence, it would be expected that external learning routines will be helpful for adjusting operations to external conditions (Kohli and Jaworski, 1990). Such external learning routines should enable the firm to build and sustain competitive advantage (Hunt and Morgan, 1995) in terms of both quality and cost improvements. This is in line with prior studies that suggest that opportunities for external learning routines may be relevant in improving quality and lowering costs (Dutton and Freedman, 1985; Meyer, 1993; Handfield, 1994; Storey, 1994; Koufteros et al., 2005). With respect to the foregoing arguments, we propose the following hypotheses:

H3a. There is a positive association between external learning routines and quality improvement.

H3b. There is a positive association between external learning routines and cost improvement.

\subsubsection{Quality improvement and cost improvement}

Historically, the relationship between "cost" and "quality" was viewed as one of tension, i.e., how can a firm provide the customer with a product offering more services, while at the same time lowering cost, ceteris paribus. Initially, those who believed that "quality is costly" always discussed cost and quality as two opposing mathematical functions that had to be optimized at some positive defect rate. Indeed this is the philosophy inherent in the now famous quality cost curves by Juran (1982). A second view, promoted by several authors (e.g. Deming, 1986; Crosby, 1996), was that "quality is free," suggesting multiple benefits from quality enhancements that result in zero defects while improving the product to exceed customer expectations and to actually "delight" them. Some benefits included an increase in customer realization (what the customer receives minus what they give up) due to quality enhancements which would shift the demand curve and, allow management either to increase price, to hold price constant and reap the benefits of returns to scale, or to choose some combination of price and scale increases, either of which would increase risk adjusted return and more than pay for the costs of increased quality.

More contemporary thought neither accepts nor rejects the premises associated with the two historically opposing arguments, but suggests that the learning routines necessary to produce better products might lead to producing better products in better ways, leading to reduction in the unit costs of inputs. This would mean that effectively, producing better products for the customer might be inextricably linked to producing them more efficiently as well, which implies lower costs. To argue oppositely would suggest that an organization's learning how to create defect free products would pay little attention to cost structure, i.e., creativity for improving quality would not spill over into improving processes. Competitive advantage in the global market requires a firm's learning activities to be oriented towards pushing quality up while simultaneously pushing costs down, allowing management greater degrees of freedom in choosing to benefit from increases in price or increases in demand, or some combination of both. Economic rationality in the current environment would suggest that management will focus on both quality and decreasing the costs of some or all inputs (Freeman et al., 2008; Gopal and Koka, 2008).

Cost and quality have long been the center of attention for manufacturing managers (Shapiro and Heskett, 1985; Hayes et al., 1988). Quality theorists and practitioners generally support the idea that quality improvements also result in cost savings that outweigh the investment in quality improvements 
(Slaughter et al., 1998). Quality improvement as an operations management objective is accepted where quality improvement is also thought to provide the additional benefit of cost reduction as waste is eliminated (Crosby, 1979, 1984; Deming, 1986). This is in support of Juran (1982), who argues that better quality practices can reduce the cost associated with quality prevention, inspection, appraisal and warranty returns. Hence, it is expected that quality improvement will improve the cost structure of a firm. Therefore, the following hypothesis is tested:

H4. There is a positive association between quality improvement and cost improvement.

\subsubsection{Quality improvement and customer satisfaction}

The idea that overall market and business performance can be enhanced through product quality improvement is the cornerstone of the contemporary quality revolution (George and Weimerskirch, 1994; National Institute of Standards and Technology, 2003). The expected positive relationship between quality improvement and customer satisfaction is consistent with the rational expectation theory (Yi, 1990), as the quality of products passing internal tests of reliability should affect the experience of customers who use the products (Ahire and Dreyfus, 2000), i.e., quality improvement should lead to increasing perceived customer satisfaction. Moreover, many leading firms such as IBM, Xerox, and 3M claim that their quality improvement efforts contribute to increased customer satisfaction (Choi and Eboch, 1998). Improvement in the quality of the product should also affect external customer satisfaction (Buzzell and Gale, 1989; Crosby, 1996; Hardie, 1998).

Based on the foregoing discussion, we argue that improvement in quality, in terms of reduction in scrap, rework, and defects, should affect customer satisfaction, in terms of reduced external failure costs. Thus, we propose the following hypothesis:

H5. There is a positive association between quality improvement and customer satisfaction.

\subsubsection{Cost improvement and firm profitability}

Cost efficiency measures assess the costs per unit of output (Berman et al., 1999). According to Porter (1980), cost improvement implies that the firm is constantly becoming more cost efficient, by improving its ability to produce at costs lower than the competition, by emphasizing efficient-scale facilities, vigorously pursuing cost reductions along the value chain driven by experience, tightly controlling cost and overhead, and minimizing cost (Spanos et al., 2004). This cost improvement strategy can also provide above-average returns because it allows the firm to lower prices to match those of competitors and still earn profits. In fact, if the product market is price elastic, demand will increase which may mean that both margins and the absolute amount of profits increase (Porter, 1985; Hambrick, 1983; Porter and Millar, 1985; Miller and Friesen, 1986). Hence, cost improvement is expected to transfer businesses' savings directly to the bottom line (Rust et al., 2002). Therefore,

H6. There is a positive association between cost improvement and firm profitability.

\subsubsection{Customer satisfaction and firm profitability}

Improvement in customer satisfaction is expected to result in increased revenue (Fornell, 1992; Hauser et al., 1994). High customer satisfaction implies high loyalty of current customers, low price elasticities, insulation of current customers from marketing efforts of competitors, and the potential to attract new customers because of enhanced reputation and, therefore, a higher revenue potential (Fornell, 1992; Hauser et al., 1994). In general, marketing literature suggests that customer satisfaction is an important indicator of a firm's overall financial health, largely because it is perceived to be a key indicator of firm profitability (Babich, 1992; Rust and Zahorik, 1993; Anderson et al., 1994). Simply stated, a satisfied customer will repeat his or her purchases of the goods or services, increasing a firm's profits (Choi and Eboch, 1998). Thus, companies that experience higher customer satisfaction may earn higher profitability (Jacobs et al., 1998, 2001). Accordingly, we test the following hypothesis:

H7. There is a positive association between customer satisfaction and firm profitability.

\subsubsection{Extent of managerial IT use and firm profitability}

In previous research employing the resource-based view, IT-performance analysis has focused on verifying that IT satisfies the principles of a strategic resource, in terms of being a source of competitive 
advantage which is valuable, limited, difficult to imitate and imperfectly substitutable (Powell and Dent-Micallef, 1997; Lado and Zhang, 1998; Bharadwaj, 2000; Meso and Smith, 2000). However, to the contrary, other studies (e.g., Clemons and Row, 1991; Mata et al., 1995; Smith et al., 1996) suggest that, while IT can potentially create value for customers, and thereby provide competitive advantage, IT is viewed as a homogeneous resource and difficult to develop in a tailored, unique or heterogeneous way to produce competitive advantage by a company. Accordingly, IT is likely to become a product which becomes available to firms via imitation and acquisition, i.e., IT may become more like a commodity acquisition than a resource that can, alone, produce competitive advantage. Powell and Dent-Micallef (1997) provide an example of this reasoning by suggesting that IT used in isolation cannot be considered as a strategic resource, but rather it is through complementary resources that IT becomes a source of competitive advantage. The technology productivity paradox then arises (Lucas, 1999), according to which IT is not transformed automatically into improved profitability for the companies using it (Real et al., 2006). As a result, Mata et al. (1995) suggest that the competitive advantages of IT lie in the organization's IT management skills and not in the technology itself. This idea has been corroborated in subsequent studies (Bharadwaj, 2000; Teo and Ranganathan, 2003) which have highlighted the significance of human and intangible resources. Based on the above, it would appear questionable whether an increase in the managerial use of IT unconditionally can be expected to result in better firm performance. Therefore, the following hypothesis is derived from this reasoning and stated in null form:

H8. The direct effect of extent of managerial IT use on firm profitability is not significant.

\section{Research design and methods}

\subsection{Questionnaire and sample}

The constructs are developed on the basis of theory and on items proposed and validated in prior studies. From these efforts, several items are generated to measure the different aspects of the constructs. Next, the questionnaire was evaluated by academics at three universities with expertise in IT, accounting, manufacturing management, and marketing.

There were 26 items (Three from Compustat and twenty-three from the survey as shown in the Appendix A) that emerged from the pilot study: five for extent of managerial IT use, four for internal learning routines, four for external learning routines, four for cost improvement, three for quality improvement, three for customer satisfaction, and three for profitability. The reliability of each construct was examined via Cronbach's (1951) alpha. All were above .70 and are indicative of internal consistency (Nunnally, 1978). Tentative evidence attesting to the unidimensionality of the constructs was provided through factor analysis. The items used in the survey were mixed throughout the instrument mailed to the respondents to make sure that the results were not an artifact of the sequence of the questions. Except for the profitability measures that were from Compustat, all survey items were based on a seven-point Likert type scale. The next step involved the collection of data through a large-scale administration.

We randomly selected 1600 manufacturing firms using the 2006-2007 Dun and Bradstreet database. ${ }^{5}$ The CEOs were used as our primary contacts. We mailed the questionnaire with self-addressed, postage-paid envelopes for returning the completed questionnaire directly to the researchers. The questionnaires were then to be completed by the CEO, the chief information officer (CIO) and/or chief operating officer (COO). ${ }^{6}$ The survey cover letter promised anonymity and described the objectives of the study. To increase the response rate, we sent follow-up letters and additional copies of the questionnaire to those who had not responded. Within the first three weeks 586 firms responded. The second mailing resulted in 122 responding firms. Overall, there were 598 usable firm responses which represent a 37.38\% response rate. Table 1 provides a more detailed analysis of sample firms included in the study.

Nonresponse bias is always a concern in survey research, thus to investigate the likelihood of nonresponse bias in the data, we compared certain key attributes of respondents (firm size in terms of the total number of employees and annual sales) to those of a group of 110 randomly selected nonrespondents. Size, as measured

\footnotetext{
${ }^{5}$ We chose manufacturing firm as we believe that most of the knowledge work takes place in such organizations.

${ }^{6}$ For precautions against retrospective biases and errors we used multiple informants.
} 
Table 1

Responses received.

\begin{tabular}{lllll}
\hline & Firms with 3 responses & Firm with 2 responses & Firm with single responses & Total \\
\hline First wave & 459 & 88 & 39 & 586 \\
Second wave & 72 & 26 & 24 & 122 \\
Total respondents & 531 & 114 & 63 & 708 \\
& & & & \\
Firms with usable responses \\
$\begin{array}{l}\text { Based on 3 responses } \\
\text { per firm } \\
433\end{array}$ & $\begin{array}{l}\text { Based on 2 responses } \\
\text { per firm } \\
89\end{array}$ & 76 & $0^{\text {a }}$ & 598 \\
\hline
\end{tabular}

a Only firms with more than one respondent are included in the sample.

by the number of employees, and sales data from Compustat and t-tests revealed no significant differences between the mean size $(t=1.27)$ and the mean sales $(t=1.31)$. To further confirm the representativeness of the sample, we tested for statistical differences in the responses between the early and late waves of survey respondents, with the last wave of surveys received considered representative of nonrespondents (Armstrong and Overton, 1977). t-Tests are performed to compare the mean scores of the early and late responses. The t-tests yield no statistically significant differences among the survey items, providing some assurance that the firms responding to the questionnaire are closely representative of the broader population surveyed (Siegel, 1956).

Next, we calculated the interrespondent reliability using a Spearman-Brown interclass correlation coefficient (Shrout and Fleiss, 1979). These results indicated that interrespondent reliability was high across all questions in the survey (ranging from 0.70 to 0.89 ). Therefore, we averaged the responses for a firm to arrive at a representation of variable values for each firm.

\subsection{Construct measures}

The seven constructs used in the proposed model in this study are extent of managerial IT use, internal learning routines, external learning routines, quality improvement, cost improvement, customer satisfaction, and firm profitability. We use a seven-point Likert scale to increase the sensitivity of the measurement instrument and because we believe that this scale is appropriate for the assumptions of factor analysis used to interpret research findings. In addition, the use of a seven-point scale is believed to be appropriate because it is the most common scale in U.S. research (Wolak et al., 1998). The constructs and their indicators are discussed below.

\subsubsection{Extent of managerial IT use}

Following Andersen (2001), we measure the extent of managerial IT use (over the past three years) on a seven-point Likert scale ( $1=$ never, $7=$ all the time) with the following inquiries: ( 1$)$ "To what extent do managers use electronic mail, etc. to communicate with different people across the organization?", (2) "To what extent do managers access information and data from other parts of the firm via the computer network?", (3) "To what extent do managers use electronic means to exchange information with manufacturing, engineering, and other functional areas?", (4) "To what extent do managers use the Internet or similar external data networks to obtain work related information?", and (5) "To what extent do managers use the Internet or other data interfaces to communicate with customers, suppliers, and other partners?"

\subsubsection{Internal learning routines}

Following Schroeder et al. (2002), we measure internal learning routines by asking respondents to indicate their agreement on the following (over the past three years): (1) "Employees are cross-trained so that they can fill in for others if necessary", (2) "Employees receive training to perform multiple tasks", (3) "Management takes all product and process improvement suggestions seriously", and (4) "Many 
useful suggestions are implemented". Responses are required using a seven-point Likert-scale $(1=$ strongly disagree, 7 = strongly agree).

\subsubsection{External learning routines}

Following Schroeder et al. (2002), respondents were asked to provide ratings on the following four items using a seven-point Likert-scale (over the past three years) ( $1=$ strongly disagree, $7=$ strongly agree): (1) "We strive to establish long-term relationships with suppliers", (2) "We maintain close communication with suppliers about quality considerations and design changes", (3) "Our customers give us feedback on quality and delivery performance", and (4) "Our customers are actively involved in the product design process".

\subsubsection{Quality improvement}

Based on Dawson and Patrickson (1991) and Ahire (1996), quality performance was measured using four indicators: (1) "scrap rate", (2) "rework rate", (3) "defect rate", and (4) "internal (before shipping) product reliability". Respondents were asked to report improvement in these indicators over a three-year time frame using a seven-point Likert scale ( 1 = "Extremely low improvement," $7=$ "Extremely high improvement").

\subsubsection{Cost improvement}

We measure cost improvement using four categories of cost borrowed from the literature (e.g., Ittner et al., 2002): materials cost, labor cost, overhead cost, and non-manufacturing cost. Respondents were asked to indicate the level of improvement in these items over the past three years using a seven-point Likert-scale ( 1 = "Extremely low improvement," 7 = "Extremely high improvement").

\subsubsection{Customer satisfaction}

Following previous studies (e.g., Sim and Killough, 1998; Ahire and Dreyfus, 2000) customer satisfaction was measured using three items. Respondents were asked to provide, on a seven-point Likert scale ( $1=$ "very low decline", 7 = "very high decline"), information on the extent to which each of the following has declined over the past three years: (1) "number of product or warranty claims", (2) "number of product litigations", and (3) "number of customer complaints".

\subsubsection{Firm profitability}

In this study, we assess firm profitability as measured by three-year average of each of the following: return on sales (ROS) - net income before corporate expenses divided by sales; turnover on assets (TOA) sales divided by total assets; and return on assets (ROA). These three measures were obtained from Compustat. Although interdependent, ROA and ROS reflect different determinants of a business success or failure (Kinney and Wempe, 2002). For example, Atkinson et al. (2001) describe asset turnover as a measure of productivity - the ability to generate sales with a given level of investment - and ROS as a measure of efficiency - the ability to control costs at a given level of sales activity. ${ }^{7}$

\section{Results}

In this section, we first present the descriptive statistics and then we examine the research model depicted in Fig. 1 using structural equation modeling with a two-stage model-building process (Joreskog and Sorbom, 1993; Hair et al., 1995; Maruyana, 1998), in which the measurement model is tested before testing the structural model. The measurement model specifies how hypothetical constructs are measured in terms of observed variables (Pijpers et al., 2001; Tan, 2001), while the structural model depicts the hypothesized relationships between latent constructs. Hence, we examine the measurement model first, followed by the structural model.

\footnotetext{
7 The DuPont analysis disaggregates return on assets (ROA) into profit margin and asset turnover. Disaggregating ROA into asset turnover and profit margin improves the accuracy of forecasting future profitability (Fairfield and Yohn, 2001Page: 26).
} 


\subsection{Descriptive statistics}

Table 2 provides descriptive information about the sample of firms and respondents used in this study. Panel A of Table 2 provides the profile of the responding companies, showing that they constitute a broad spectrum of manufacturers as defined by the two-digit SIC code. The sample composition has the largest representation in electronic and electrical equipment (13.21\%), chemical and allied products (11.87\%), apparel and other textile products (9.20\%), food and kindred products (8.53\%), paper and allied products (8.53\%) followed by instruments and related products (7.69\%) and primary metal industries (6.86\%). The size of the companies represented in the sample is measured by the average number of employees, which is 1841 , and mean sales which is $\$ 11.62$ million. Additional information on respondents' characteristics is provided in Panel B of Table 2. Answers to the question regarding number of years at present position showed that the respondents have a mean of 13.17 years in their current position. To the number-of-years-in-management question, respondents indicated a mean of 17.24 years. It appears from their positions and tenure that the respondents are knowledgeable and experienced, have access to information upon which to provide reliable perceptions, and are otherwise well qualified to provide the information required.

Table 2, Panel C reports the mean, standard deviations, minimum and maximum of the construct items used in the study.

\subsection{Measurement and structural model methods}

The measurement model is tested first, followed by testing the structural model. This is done to avoid the possible interactions between the measurement and structural models. In addition, confirmatory factor analysis (CFA) is performed on a covariance matrix using maximum likelihood estimation and on the entire set of items simultaneously (Anderson and Gerbing, 1988). Convergent validity is assessed by examining the significance of individual item loadings through t-tests. The overall fit of a hypothesized model is assessed using fit indices such as the ratio of chi-square to degrees of freedom, Bentler and Bonnet's (1980) normed fit index (NFI), Bentler's (1980) comparative fit index (CFI), James et al. (1982) goodness-of-fit index (GFI), and Steiger and Lind's (1980) root mean square error of approximation (RMSEA). Discriminant validity is assessed by comparing the average variance extracted (AVE) to the squared correlation between constructs (Fornell and Larcker, 1981). Reliability estimation is tested last because in the absence of a valid construct, reliability may not be relevant (Koufteros, 1999). To test hypotheses, a structural model is evaluated, and if the model fits the data adequately, the t-values of the structural coefficients (i.e., $\gamma$ and $\beta$ ) can be used to test the research hypotheses.

\subsubsection{Measurement model}

The posited measurement model is supported by various fit indices. The fit indices, along with t-values, provide evidence of convergent as well as discriminant validity (Table 4). The ratio chi-square to degrees of freedom results in a ratio of 2.57. The CFI was 0.93 and NFI is 0.92 , whereas the GFI is 0.90 and the RMSEA is 0.058. All of the items have statistically significant relationships with their factors. All factor loadings are above 0.70 and most above 0.80 . The significance of the t-values (Table 3 ) associated with factor to item loadings exceeds the critical value at the .05 significance level.

Table 4 provides the correlations among the constructs, composite reliabilities, and average variance extracted (AVE). Evidence of discriminant validity is provided by comparing the squared correlation of two constructs against their individual AVE. The squared correlations are lower than their corresponding AVE for the latent variables. The composite reliabilities and AVE estimates for each construct exceed customary acceptable levels. Overall, there is comforting support for the models to allow proceeding with an evaluation of the structural model and hypotheses testing.

\subsubsection{Structural model}

The overall structural model fit appears to be reasonable (e.g., chi-square to degrees of freedom $=2.73$, $\mathrm{GFI}=0.96, \mathrm{NFI}=0.92, \mathrm{CFI}=0.94$, and RMSEA $=0.039$ ) (Table 5 ), and we proceed with testing of hypotheses. Next, we examine the standardized parameter estimates for our model by using the significance of individual path coefficients to evaluate the hypotheses. Hypotheses H1a and H1b state that extent of managerial IT use is associated with both internal learning routines and external learning routines. The results 
Table 2

Respondents' characteristics.

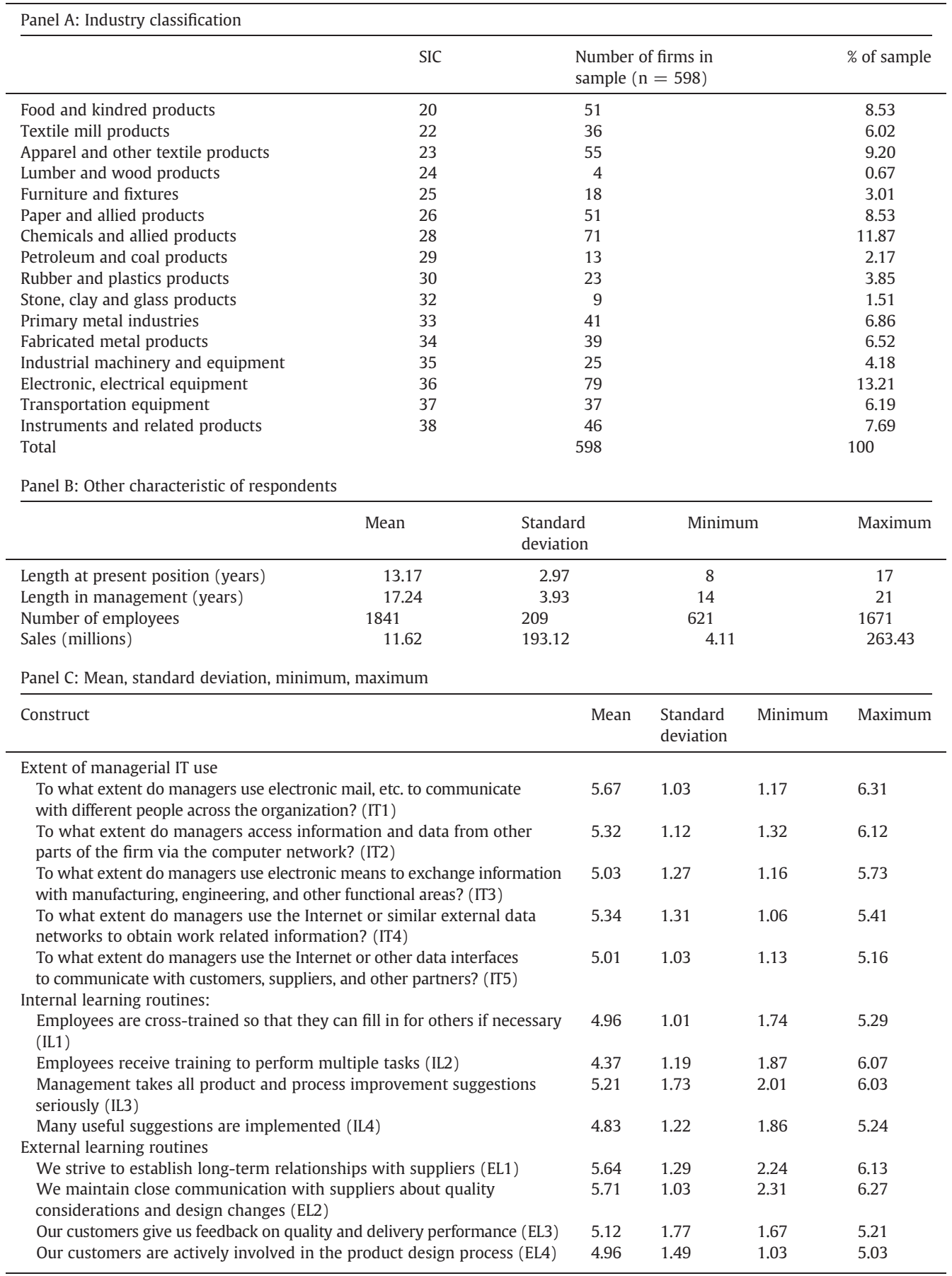


Table 2 (continued)

\begin{tabular}{|c|c|c|c|c|}
\hline Construct & Mean & $\begin{array}{l}\text { Standard } \\
\text { deviation }\end{array}$ & Minimum & Maximum \\
\hline \multicolumn{5}{|l|}{ Quality improvement } \\
\hline Finished product first-pass quality yield in percentage terms (QI1) & 5.17 & 1.28 & 2.13 & 5.39 \\
\hline Scrap cost as a percentage of sales (QI2) & 4.73 & 1.02 & 2.03 & 5.56 \\
\hline Rework cost as a percentage of sales (QI3) & 5.23 & 1.37 & 1.79 & 5.03 \\
\hline \multicolumn{5}{|l|}{ Cost improvement } \\
\hline Direct materials costs (CI1) & 3.93 & 1.01 & 1.13 & 5.32 \\
\hline Direct labor costs $(\mathrm{Cl} 2)$ & 5.38 & 1.15 & 1.24 & 5.38 \\
\hline Overhead costs (CI3) & 4.23 & 1.06 & 1.71 & 5.34 \\
\hline Non-manufacturing costs (Cl4) & 4.61 & 1.26 & 1.79 & 5.07 \\
\hline \multicolumn{5}{|l|}{ Customer satisfaction } \\
\hline $\begin{array}{l}\text { There has been a steady decline in the number of warranty claims } \\
\text { over the last three years (CS1) }\end{array}$ & 4.56 & 1.18 & 1.73 & 5.79 \\
\hline $\begin{array}{l}\text { There has been a steady decline in the number of product } \\
\text { litigation claims over the last three years (CS2) }\end{array}$ & 5.43 & 1.05 & 2.16 & 6.03 \\
\hline $\begin{array}{l}\text { There has been a steady decline in the number of customer } \\
\text { complaints over the last three years (CS3) }\end{array}$ & 5.33 & 1.62 & 1.93 & 6.17 \\
\hline \multicolumn{5}{|l|}{ Profitability } \\
\hline $\begin{array}{l}\text { Return on sales (net income before corporate expenses divided by sales) } \\
\text { (P1) }\end{array}$ & 0.02 & 0.03 & 0.02 & 0.07 \\
\hline Turnover on assets (sales divided by total assets) (P2) & 1.61 & 0.51 & 0.93 & 2.12 \\
\hline $\begin{array}{l}\text { Return on assets (net income before corporate taxes divided by total assets) } \\
\text { (P3) }\end{array}$ & 0.04 & 0.02 & 0.002 & 0.08 \\
\hline
\end{tabular}

support these hypotheses (Table 5 and Fig. 2). Specifically, higher levels of IT use are associated with both higher levels of internal learning routines $\left(\gamma_{1,1}=0.13, t=3.12\right)$ and external learning routines $\left(\gamma_{2,1}=\right.$ $0.19, \mathrm{t}=4.71$ ). IT use may be necessary if both internal and external learning routines are to materialize at significant levels.

Internal learning routines are hypothesized to be associated with quality improvement (H2a) and cost improvement $(\mathrm{H} 2 \mathrm{~b})$. The results indicate that internal learning routines has a statistically significant and positive relationship with quality improvement $\left(\beta_{3,1}=0.19, \mathrm{t}=3.27\right)$ and cost improvement $\left(\beta_{4,1}=0.48\right.$, $t=13.12)$. Similarly, external learning routines are hypothesized to affect quality improvement (H3a) and cost improvement $(\mathrm{H} 3 \mathrm{~b})$. The results indicate that external learning routines has a statistically significant and positive relationship with quality improvement $\left(\beta_{3,2}=0.21, t=3.71\right)$ and cost improvement $\left(\beta_{4,2}=0.14\right.$, $t=3.19$ ). Businesses that possess the ability to learn rapidly about their markets and act on that information are best positioned to achieve competitive advantage (Day, 1993, 1994; Slater and Narver, 1994, 1995; Tuominen et al., 1997). Hence, the contributions of both internal and external learning routines in enhancing firm operational performance cannot be ignored.

Hypotheses $\mathrm{H} 4$ and $\mathrm{H} 5$ suggest that quality improvement is associated with both cost improvement and customer satisfaction. The data support these assertions and indicate that higher levels of quality improvement are related to higher levels of cost improvement $\left(\beta_{4,3}=0.23, t=4.92\right)$ and customer satisfaction $\left(\beta_{5,3}=0.26, \mathrm{t}=5.21\right)$.

Hypothesis $\mathrm{H} 6$ argued for a positive association between cost improvement and firm profitability. Similarly, H7 suggests that customer satisfaction has a significant positive effect on firm profitability. These hypotheses are strongly supported. Higher levels of cost improvement and customer satisfaction are associated with higher levels of profitability $\left(\beta_{6,5}=0.17, \mathrm{t}=3.47\right.$ and $\beta_{6,4}=0.21, \mathrm{t}=3.79$, respectively). This suggests that both cost improvement and quality improvement may be indispensable in the quest for firm profitability. Thus, H1a through $\mathrm{H} 7$ are supported.

Table 4 shows that the relationship between extent of managerial IT use and profitability has a significant correlation $(0.09, \mathrm{p}<0.10)$. However, after controlling for the indirect effect of $0.02(t=1.99)$, the direct effect of 0.01 is not significant $(t=1.13)$. This means that the effect of extent of managerial IT use on profitability is indirect through intervening variables. Therefore, H8 is supported. Table 5 and Fig. 2 show the estimates of the direct and indirect path coefficients. 
Table 3

Analysis of measurement model.

\begin{tabular}{|c|c|c|}
\hline Construct & Standardized loading & t-Value \\
\hline \multicolumn{3}{|l|}{ Extent of managerial IT use } \\
\hline $\begin{array}{l}\text { To what extent do managers use electronic mail, etc. to communicate with different people } \\
\text { across the organization? (IT1) }\end{array}$ & 0.73 & 21.65 \\
\hline $\begin{array}{l}\text { To what extent do managers access information and data from other parts of the firm via } \\
\text { the computer network? (IT2) }\end{array}$ & 0.81 & 24.87 \\
\hline $\begin{array}{l}\text { To what extent do managers use electronic means to exchange information with } \\
\text { manufacturing, engineering, and other functional areas? (IT3) }\end{array}$ & 0.76 & 21.53 \\
\hline $\begin{array}{l}\text { To what extent do managers use the Internet or similar external data networks to obtain } \\
\text { work related information? (IT4) }\end{array}$ & 0.87 & 26.71 \\
\hline $\begin{array}{l}\text { To what extent do managers use the Internet or other data interfaces to communicate } \\
\text { with customers, suppliers, and other partners? (IT5) }\end{array}$ & 0.85 & $-{ }^{a}$ \\
\hline \multicolumn{3}{|l|}{ Internal learning routines } \\
\hline Employees are cross-trained so that they can fill in for others if necessary (IL1) & 0.75 & 20.79 \\
\hline Employees receive training to perform multiple tasks (IL2) & 0.97 & 29.63 \\
\hline Management takes all product and process improvement suggestions seriously (IL3) & 0.86 & 25.76 \\
\hline Many useful suggestions are implemented (IL4) & 0.81 & $-{ }^{\mathrm{a}}$ \\
\hline \multicolumn{3}{|l|}{ External learning routines } \\
\hline We strive to establish long-term relationships with suppliers (EL1) & 0.83 & 25.16 \\
\hline $\begin{array}{l}\text { We maintain close communication with suppliers about quality considerations and } \\
\text { design changes (EL2) }\end{array}$ & 0.91 & 31.42 \\
\hline Our customers give us feedback on quality and delivery performance (EL3) & 0.96 & 35.07 \\
\hline Our customers are actively involved in the product design process (EL4) & 0.87 & $-\mathrm{a}$ \\
\hline \multicolumn{3}{|l|}{ Quality improvement } \\
\hline Finished product first-pass quality yield in percentage terms (QI1) & 0.84 & 31.51 \\
\hline Scrap cost as a percentage of sales (QI2) & 0.81 & 25.87 \\
\hline Rework cost as a percentage of sales (QI3) & 0.97 & $-{ }^{\mathrm{a}}$ \\
\hline \multicolumn{3}{|l|}{ Cost improvement } \\
\hline Direct materials costs (CI1) & 0.85 & 27.41 \\
\hline Direct labor costs $(\mathrm{CI} 2)$ & 0.79 & 24.68 \\
\hline Overhead costs (CI3) & 0.84 & 27.23 \\
\hline Non-manufacturing costs $(\mathrm{Cl} 4)$ & 0.81 & $-{ }^{a}$ \\
\hline \multicolumn{3}{|l|}{ Customer satisfaction } \\
\hline $\begin{array}{l}\text { There has been a steady decline in the number of warranty claims over the last three } \\
\text { years (CS1) }\end{array}$ & 0.83 & 27.08 \\
\hline $\begin{array}{l}\text { There has been a steady decline in the number of product litigation claims over the last } \\
\text { three years (CS2) }\end{array}$ & 0.72 & 21.69 \\
\hline $\begin{array}{l}\text { There has been a steady decline in the number of customer complaints over the last three } \\
\text { years (CS3) }\end{array}$ & 0.85 & $--^{a}$ \\
\hline \multicolumn{3}{|l|}{ Profitability } \\
\hline Return on sales (net income before corporate expenses divided by sales) (P1) & 0.84 & 27.21 \\
\hline Turnover on assets (sales divided by total assets) (P2) & 0.89 & 28.13 \\
\hline Return on assets (net income before corporate taxes divided by total assets) (P3) & 0.82 & $-{ }^{\mathrm{a}}$ \\
\hline
\end{tabular}

Fit indices: $\chi^{2} / \mathrm{df}=2.35, \mathrm{GFI}=0.91, \mathrm{NFI}=0.92, \mathrm{CFI}=0.94$, IFI $=0.94$, and RMSEA $=0.037$.

a Indicates a parameter is fixed at 1.0 in the original solution.

Next, in addition to testing H8, we also test the non-hypothesized paths by performing between-model comparisons using the $\chi^{2}$ difference test recommended by Bollen (1989) and others (e.g., Hayduk, 1987; Joreskog and Sorbom, 1993; Medsker et al., 1994), along with differences in the fit indices (Anderson and Gerbing, 1988; Medsker et al., 1994) to evaluate the relative fit of our best-fitting model and the non-nested alternative model. The $\chi^{2}$ difference test examines the gain in predictive power of one nested model over another one in terms of change in $\chi^{2}$.

The following models are tested using the proposed theoretical model (model 1) as the baseline model and tested for the significance of incremental increases in model fit due to non-hypothesized direct effects: (2) model 2 tests the relationship between extent of managerial IT use and quality improvement, (3) model 3 tests the relationship between extent of managerial IT use and cost improvement, (4) model 4 tests the relationship between extent of managerial IT use and customer satisfaction, model 5 tests the relationship between extent of managerial IT use and profitability, (6) model 6 tests the relationship between internal 
Table 4

Correlation, reliability, and average variance extracted.

\begin{tabular}{llllllll}
\hline & 1 & 2 & 3 & 4 & 5 & 6 & 7 \\
\hline (1) Extent of managerial IT use & 1 & & & & & \\
(2) Internal learning routines & $0.13^{\mathrm{a} * * *}, 0.02^{\mathrm{b}}$ & 1 & & & & & \\
(3) External learning routines & $0.17^{* * *}, 0.03$ & $0.21^{* * *}, 0.03$ & 1 & & & \\
(4) Quality improvement & $0.11,0.00$ & $0.14^{* * *}, 0.02$ & $0.19^{* * *}, 0.04$ & 1 & & \\
(5) Cost improvement & $0.14^{* *}, 0.00$ & $0.51^{* * *}, 0.24$ & $0.22^{* * *}, 0.05$ & $0.28^{* * *}, 0.06$ & 1 & & \\
(6) Customer satisfaction & $0.03^{*}, 0.00$ & $0.08^{*}, 0.00$ & $0.04^{*}, 0.00$ & $0.22^{* * *}, 0.03$ & $0.07^{*}, 0.00$ & 1 \\
(7) Profitability (ROA) & $0.09^{*}, 0.00$ & $0.04^{*}, 0.00$ & $0.07^{*}, 0.00$ & $0.10^{* *}, 0.00$ & $0.16^{* * *}, 0.03$ & $0.17^{* * *}, 0.01$ & 1 \\
Reliability & 0.89 & 0.93 & 0.91 & 0.92 & 0.83 & 0.90 & 0.89 \\
Variance extracted & 0.73 & 0.79 & 0.80 & 0.87 & 0.80 & 0.88 & 0.76 \\
\hline
\end{tabular}

For discriminant validity, average variance extracted (diagonal elements denoted b) should be larger than the square correlations (off-diagonal elements denoted b) (Fornell and Larcker, 1981).

${ }^{\text {a }}$ Correlation [ ${ }^{*}$ significant at the 0.10 level, ${ }^{* *}$ significant at the 0.05 level, ${ }^{* * *}$ significant at the 0.01 level (2-tailed)].

b Square correlation.

learning routines and customer satisfaction, (7) model 7 tests the relationship between internal learning routines and profitability, (8) model 8 tests the relationship between external learning routines and customer satisfaction, (9) model 9 tests the relationship between external learning routines and profitability, (10) model 10 tests the relationship between cost improvement and customer satisfaction, and (11) model 11 tests the relationship between quality improvement and profitability.

Results in Table 6 indicate that none of the $\chi^{2}$ difference tests is significant at the .05 level, suggesting none of the fit indices of the alternative models show an improvement over the proposed theoretical model, thereby reinforcing our finding that the theoretical model is the best-fitting model. In addition, there are no significant paths between the variables that are not originally identified that would further explain the impact on performance. Hence, we do not include any additional paths in a fully saturated model. The results support our contention that both quality improvement and cost improvement are intervening variables that mediate the relationships between the IT use and profitability. The results also support prior studies that suggest that there is no direct connection between extent of managerial IT use and performance (Banker and Kauffman, 1988; Floyd and Woolridge, 1990; Mahmood and Soon, 1991; Zahra and Covin, 1993; Kettinger et al., 1994; Hitt and Brynjolfsson, 1996; Powell and Dent-Micallef, 1997; Makadok, 2001). Rather, the impact of extent of managerial IT use on performance is achieved through

Table 5

Structural path coefficients.

\begin{tabular}{lll}
\hline Path & Direct effects (t-value) & Indirect effects (t-value) \\
\hline Extent of managerial IT usage $\rightarrow$ internal learning routines & $0.13(3.12)$ & - \\
Extent of managerial IT usage $\rightarrow$ external learning routines & $0.19(4.71)$ & - \\
Extent of managerial IT usage $\rightarrow$ quality improvement & - & $0.65(7.94)$ \\
Extent of managerial IT usage $\rightarrow$ cost improvement & - & $0.11(2.32)$ \\
Extent of managerial IT usage $\rightarrow$ customer satisfaction & - & $0.02(1.91)$ \\
Extent of managerial IT usage $\rightarrow$ profitability & $0.01(1.13)$ & $0.02(1.99)$ \\
Internal learning routines $\rightarrow$ quality improvement & $0.19(3.27)$ & - \\
Internal learning routines $\rightarrow$ cost improvement & $0.48(13.12)$ & $0.04(2.65)$ \\
Internal learning routines $\rightarrow$ customer satisfaction & - & $0.05(3.01)$ \\
Internal learning routines $\rightarrow$ profitability & - & $0.09(5.92)$ \\
External learning routines $\rightarrow$ quality improvement & $0.21(3.71)$ & - \\
External learning routines $\rightarrow$ cost improvement & $0.14(3.19)$ & $0.05(3.93)$ \\
External learning routines $\rightarrow$ customer satisfaction & - & $0.06(5.76)$ \\
External learning routines $\rightarrow$ profitability & - & $0.02(1.95)$ \\
Quality improvement $\rightarrow$ customer satisfaction & $0.26(5.21)$ & - \\
Quality improvement $\rightarrow$ cost improvement & $0.23(4.92$ & - \\
Quality improvement $\rightarrow$ profitability & - & $0.09(2.23)$ \\
Cost improvement $\rightarrow$ profitability & $0.17(3.47)$ & - \\
Customer satisfaction $\rightarrow$ profitability & $0.21(3.79)$ & \\
\hline
\end{tabular}

Fit indices: $\chi^{2} / \mathrm{df}=2.73, \mathrm{GFI}=0.96, \mathrm{NFI}=0.92, \mathrm{CFI}=0.94$, and RMSEA $=.039$. 


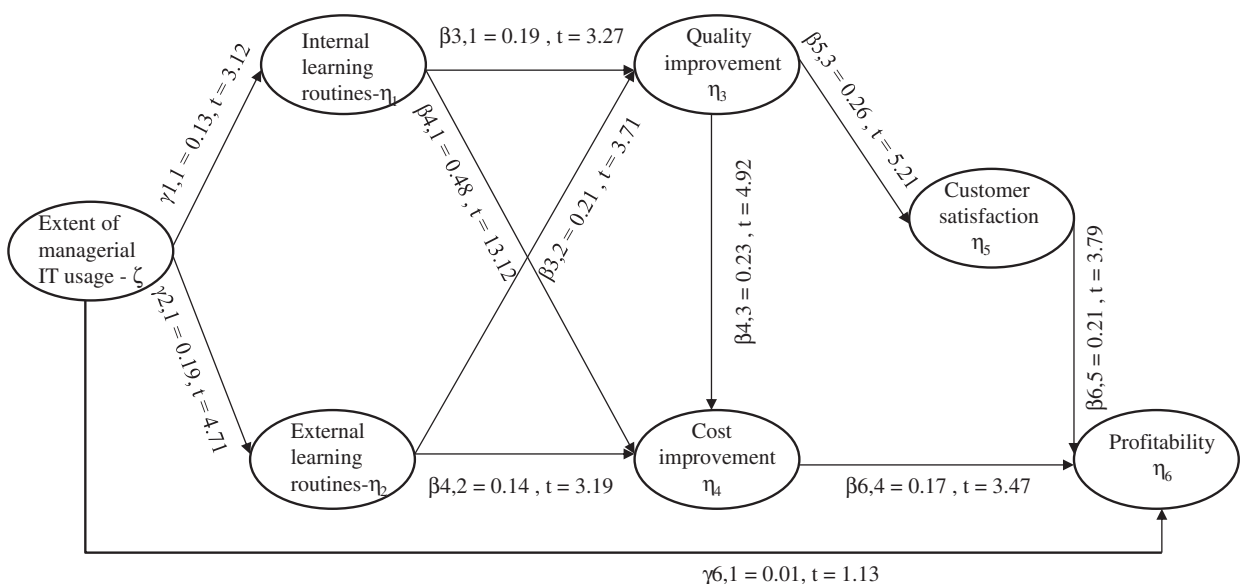

Note: For the sake of brevity, errors and disturbance terms are not shown.

Fig. 2. Structural model path coefficients and significance.

intermediate organizational capabilities (Sambamurthy and Zmud, 1994; Barua and Mukhopadhyay, 2000; Sambamurthy et al., 2003). Therefore, H8 is supported.

\subsection{Further analyses}

While IT can affect firm financial performance via learning routines and in other ways that enhance competitive advantages, as noted earlier, these results could differ between industries. For example, Summers (2005) argue that the widespread adoption of IT enabled fundamental changes in the nature of production and distribution processes, and their relationship to final sales, especially for durable goods, suggesting differences in the way IT impacts durable and nondurable goods industries. Therefore, the question is whether the structural relationships depicted in the research model (Fig. 1) are invariant across the two industry groups suggested by Summers (2005). To ascertain whether the structural relationships are invariant, it is important, however, to first establish measurement model invariance using the two industry sub-samples (i.e., durable and nondurable goods industries).

The additional analyses called for a differential effect on the pattern of linkages in Fig. 1 according to industry groups. The $\chi^{2}$ (876.33) of a baseline model (Model 1) with 321 degrees of freedom was compared against the $\chi^{2}$ (908.14) for a model (Model 2) that specified invariance for the $\Lambda_{\mathrm{x}}$ and $\Lambda_{\mathrm{y}}$ matrices with 339 degrees of freedom (see Table 7). Next, the model was estimated by constraining the number of factors and the factor loadings for the specific items defining each factor across the two manufacturing groups to be

Table 6

Results for model comparison Tests.

\begin{tabular}{llllllll}
\hline & $\Delta \chi^{2}$ & GFI & NFI & CFI & IFI & RMSEA & Significance \\
\hline 1. Model 1 (theoretical model) & - & 0.96 & 0.92 & 0.94 & 0.92 & 0.03 & s.* $^{*}$ \\
2. Extent of managerial IT use-quality improvement & 1.10 & 0.92 & 0.93 & 0.91 & 0.91 & 0.04 & n.s. $^{* *}$ \\
3. Extent of managerial IT use-cost improvement & 1.03 & 0.89 & 0.91 & 0.89 & 0.91 & 0.07 & n.s. \\
4. Extent of managerial IT use-customer satisfaction & 1.27 & 0.91 & 0.91 & 0.91 & 0.92 & 0.05 & n.s. \\
5. Internal learning routines-customer satisfaction & 1.27 & 0.92 & 0.91 & 0.91 & 0.91 & 0.06 & n.s. \\
6. Internal learning routines-profitability & 1.19 & 0.90 & 0.91 & 0.92 & 0.92 & 0.06 & n.s. \\
7. External learning routines-customer satisfaction & 1.08 & 0.89 & 0.91 & 0.93 & 0.91 & 0.09 & n.s. \\
8. External learning routines-profitability & 1.17 & 0.90 & 0.89 & 0.91 & 0.90 & 0.06 & n.s. \\
9. Cost improvement-customer satisfaction & 1.13 & 0.92 & 0.90 & 0.92 & 0.91 & 0.07 & n.s. \\
10. Quality improvement-profitability & 1.07 & 0.90 & 0.88 & 0.90 & 0.89 & 0.06 & n.s. \\
\hline
\end{tabular}

\footnotetext{
$* \mathrm{~s}=$ significant.

*** n.s. = not significant.
} 
Table 7

Invariance test across two industry groups (durable goods and nondurable goods) and path analyses.

\begin{tabular}{|c|c|c|c|c|c|c|c|c|c|c|c|}
\hline & $\chi^{2}$ & df & $\chi^{2} / \mathrm{df}$ & NNFI & CFI & Nested models & $\Delta \chi^{2}$ & $\Delta \mathrm{df}$ & Sign. level & $\begin{array}{l}\text { Durable goods coeff. } \\
\text { (t-values) }\end{array}$ & $\begin{array}{l}\text { Nondurable goods coeff. } \\
\text { (t-values) }\end{array}$ \\
\hline 1. Base model & 876.33 & 321 & 2.73 & 0.986 & 0.986 & & & & & & \\
\hline 2. Equal loadings & 908.14 & 339 & 2.68 & 0.984 & 0.986 & $2-1$ & 33.19 & 18 & ns & & \\
\hline 3. Equal loading, factor correlations & 909.95 & 343 & 2.65 & 0.978 & 0.986 & $3-2$ & 1.81 & 4 & ns & & \\
\hline 4. Equal loadings, factor correlations, measurement model & 922.75 & 366 & 2.52 & 0.979 & 0.984 & $4-3$ & 13.20 & 23 & ns & & \\
\hline $\begin{array}{l}\text { 5. Equal loadings, factor correlations, measurement error, } \\
\text { structural coefficient }\end{array}$ & 942.93 & 371 & 2.54 & 0.981 & 0.981 & $5-4$ & 20.18 & 5 & s & & \\
\hline 6a. Extent of managerial IT use $\rightarrow$ internal learning routines & 930.11 & 367 & 2.53 & 0.981 & 0.984 & $6 a-4$ & 21.97 & 1 & s & $0.17(4.38)$ & $0.35(1.57)$ \\
\hline 6b. Extent of managerial IT use $\rightarrow$ external learning routines & 932.61 & 367 & 2.54 & 0.981 & 0.984 & $6 b-4$ & 9.86 & 1 & s & $0.26(3.59)$ & $0.11(1.38)$ \\
\hline $6 c$. Internal learning routines $\rightarrow$ quality improvement & 925.47 & 367 & 2.52 & 0.981 & 0.984 & $6 c-4$ & 2.72 & 1 & s & $0.48(2.01)$ & $0.37(0.89)$ \\
\hline $6 \mathrm{~d}$. External learning routines $\rightarrow$ quality improvement & 933.37 & 367 & 2.54 & 0.981 & 0.984 & $6 d-4$ & 10.62 & 1 & s & $0.09(5.23)$ & $0.27(1.21)$ \\
\hline 6e. Internal learning routines $\rightarrow$ cost improvement & 933.82 & 367 & 2.54 & 0.981 & 0.984 & $6 e-4$ & 11.07 & 1 & s & $0.27(3.93)$ & $0.04(1.03)$ \\
\hline 6f. External learning routines $\rightarrow$ cost improvement & 925.23 & 367 & 2.52 & 0.981 & 0.984 & $6 f-4$ & 2.48 & 1 & s & $0.15(3.45)$ & $0.54(0.86)$ \\
\hline 6g. Quality improvement $\rightarrow$ cost improvement & 923.78 & 367 & 2.52 & 0.981 & 0.984 & $6 g-4$ & 1.03 & 1 & ns & $0.15(3.32)$ & $0.10(2.14)$ \\
\hline 6h. Quality improvement $\rightarrow$ customer satisfaction & 924.01 & 367 & 2.52 & 0.981 & 0.984 & $6 h-4$ & 1.26 & 1 & ns & $0.38(5.38)$ & $0.21(4.39)$ \\
\hline 6i. Cost improvement $\rightarrow$ profitability & 923.96 & 367 & 2.52 & 0.981 & 0.984 & $6 \mathrm{i}-4$ & 1.21 & 1 & ns & $0.29(6.10)$ & $0.13(4.28)$ \\
\hline 6j. Customer satisfaction $\rightarrow$ profitability & 924.22 & 367 & 2.52 & 0.981 & 0.984 & $6 j-4$ & 1.47 & 1 & ns & $0.15(3.84)$ & $0.07(2.98)$ \\
\hline 6k. Extent of managerial IT use $\rightarrow$ profitability & 924.31 & 367 & 2.52 & 0.981 & 0.984 & $6 \mathrm{k}-4$ & 1.56 & 1 & ns & $0.35(1.15)$ & $0.29(1.04)$ \\
\hline
\end{tabular}

$\mathrm{s}=$ significant and $\mathrm{ns}=$ not significant. 
invariant. The $\chi^{2}$ difference test (that enables one to compare a more constrained model to a less constrained one - i.e., Model 2 compared to Model 1$)$ did not result in a deterioration of model fit $\left(\chi^{2}{ }_{\mathrm{M} 2}-\chi^{2}{ }_{\mathrm{M} 1}=33.19\right.$ with 15 degrees of freedom, $p>0.10$ ). Thus, there is no evidence to indicate that the same factors and factor loadings for specific items defining each factor were different for durable and nondurable goods industries.

Further, another model was tested by constraining the number of factors, the factor loadings, as well as the factor inter-correlations across the two manufacturing groups to be the same. The results provided a $\chi^{2}$ of 909.95 with 343 degrees of freedom and indicated that the additional constraints imposed in this model (Model 3) did not result in model fit deterioration over Model $2\left(\chi^{2}{ }_{\mathrm{M} 3}-\chi^{2}{ }_{\mathrm{M} 2}=2.65\right.$ with 4 degrees of freedom, $\mathrm{p}>0.10$ ), thereby implying that durable and nondurable goods industries do not differ in terms of their factors, factor loadings, and factor inter-correlations proposed in Fig. 1.

In order to test for equality of measurement error (i.e., error variance) across the two groups, a fourth constrained model was estimated. This constrained model specified the same factor structure, with equal factor loadings, factor correlations, and error variances across the two groups. This model (Model 4) provided a $\chi^{2}$ of 922.75 with 366 degrees of freedom and indicated that the additional constraints imposed on this model (i.e., the equal measurement errors or error variances) led to a non-statistically significant fit over Model $3\left(\chi^{2}{ }_{\mathrm{M} 4}-\chi^{2}{ }_{\mathrm{M} 3}=13.20\right.$ with 23 degrees of freedom and a $\left.\mathrm{p}>0.10\right)$, thereby implying that small and large firms do not differ in terms of number of factors, factor loading, factor correlations, and measurement error. On the aggregate, data analyses suggest that the measurement model is invariant across the durable and nondurable goods industries.

The next set of analyses involved testing for the invariance of the structural coefficients (i.e., the B's and $\Gamma$ 's in the model). This model (Model 5) provided a $\chi^{2}$ value of 942.93 with 371 degrees of freedom and indicated that the additional constraints imposed led to a statistically significant deterioration of model fit $\left(\chi_{\mathrm{M} 5}^{2}-\right.$ $\chi_{\mathrm{M} 4}^{2}=20.181$ with 5 degrees of freedom and a $\left.\mathrm{p} \leq 0.001\right)$. It appears that there were at least some differences in path coefficients across durable and non-durable goods industry. As such, a search procedure was followed in order to identify exactly which path coefficients were different for the two groups considered.

In order to identify which path coefficients are different across groups, testing involved simultaneously testing two models at a time, i.e., Model 4 and one other model from Table 7 that shows a path coefficient as invariant. This involved the testing of two models at a time: Model 4 and one in which one path coefficient at a time is specified as invariant (Table 7). Thus, the difference in degrees of freedom between each set of two models was one, noting that $\chi^{2}$ differences $\left(\Delta \chi^{2}\right)$ greater than 3.84 are statistically significant at an alpha of 05 . This was the case for six coefficients. The $\gamma$ coefficient that describes the relationship between extent of managerial IT use and internal learning routines was different $\left(\chi^{2}\right.$ difference $\left.=21.97\right)$. Also, the relationship between extent of managerial IT use and external learning routines was different ( $\chi^{2}$ difference $=9.86$ ). It appears that extent of managerial IT use was more conducive for both internal and external learning routines for durable goods firms ( $\mathrm{t}=4.38, \mathrm{p}<.01, \mathrm{t}=3.69, \mathrm{p}<0.01$, respectively) but was a weak predictor of both internal and external learning routines for nondurable goods firms $(t=1.57, p>0.10$, and $t=1.38, p>0.10$, respectively). ${ }^{8}$

Similarly, the $\gamma$ coefficient that describes the relationship between internal learning routines and quality improvement was different $\left(\chi^{2}\right.$ difference $=2.72$ ). The relationship between internal learning routines and cost improvement was also different $\left(\chi^{2}\right.$ difference $\left.=11.07\right)$. Thus, the implication from these findings are that internal learning routines was more conducive for quality improvement and cost improvement for durable goods firms ( $\mathrm{t}=2.01, \mathrm{p}<0.01$, and $\mathrm{t}=3.93, \mathrm{p}<0.01$, respectively), but was not a significant predictor of quality improvement and cost improvement for nondurable goods firms $(t=0.89, \mathrm{p}>0.10$, and $\mathrm{t}=1.03$, $\mathrm{p}>0.10$, respectively). Also, the $\gamma$ coefficient that describes the relationship between external learning routines and quality improvement was different $\left(\chi^{2}\right.$ difference $\left.=10.62\right)$. The relationship between external learning routines and cost improvement was also different $\left(\chi^{2}\right.$ difference $\left.=2.48\right)$, suggesting that external learning routines was more conducive for quality improvement and cost improvement for durable goods firms $(t=$ $5.23, \mathrm{p}<0.01$, and $\mathrm{t}=3.45, \mathrm{p}<0.01$, respectively), but was not a significant predictor of quality improvement and cost improvement for nondurable goods firms $(t=1.21, p>0.10$, and $t=0.86, p>0.10$, respectively).

However, the effect of quality improvement on cost improvement was not sample specific $\left(\chi^{2}\right.$ difference $=1.03$ ). The effect was statistically significant for both durable and nondurable goods firms

${ }^{8}$ Ordinarily, durable goods manufacturing includes the IT-producing sector (Dedrick et al., 2003). 
( $\mathrm{t}=3.32$, $\mathrm{p}$-value $<0.01$ and $\mathrm{t}=2.13, \mathrm{p}<0.05$, respectively). Also, the effect of quality improvement on customer satisfaction was not sample specific $\left(\chi^{2}\right.$ difference $\left.=1.26\right)$. The effect was statistically significant for both durable and nondurable goods firms ( $\mathrm{t}=5.38, \mathrm{p}<1$ and $\mathrm{t}=4.39, \mathrm{p}<0.01$, respectively). Furthermore, the effect of cost improvement on profitability was not sample specific $\left(\chi^{2}\right.$ difference $\left.=1.21\right)$ because the effect was statistically significant for both durable and nondurable goods firms $(\mathrm{t}=6.10, \mathrm{p}<0.01$ and $\mathrm{t}=$ $4.28, \mathrm{p}<0.01$, respectively). Results also indicated that relationship between customer satisfaction and profitability was specific to industry group $\left(\chi^{2}\right.$ difference $\left.=1.47\right)$, and the relationship was significant for both groups ( $\mathrm{t}=3.84, \mathrm{p}<0.01$ and $\mathrm{t}=2.98, \mathrm{p}<0.05$, respectively). Finally, the direct relationship between extent of managerial IT use and profitability was not industry group specific $\left(\chi^{2}\right.$ difference $\left.=1.56\right)$, and the relationship was not significant for both groups ( $t=1.15, \mathrm{p}>0.10$ for durable goods, and $t=1.04, \mathrm{p}>0.10$ for nondurable goods). Hence, the analysis reveals that industry moderates the relationship among the variables under study, and that the effects are in general more pronounced for durable goods firms.

\section{Conclusions}

This research points to the need for an integrated theory to explain how the use of IT may be mobilized to positively affect firm profitability. Although several different theoretical perspectives from a variety of disciplines address specific aspects of this subject, the field lacks adequate organizational control theory to fully address these critical business issues. Recently, scholars have directed increased attention to understanding how IT may impact performance. By reviewing the literature, developing a model, and identifying key variables as well as relationships, we provide another step toward more completely understanding this topic.

The results of this study indicate that greater managerial IT use is associated with internal and external learning routines, that is, firms that reported high levels of managerial IT use also reported high levels of both internal and external learning routines. Furthermore, high levels of learning routines (internal and external) are related to improved quality and costs. This suggests that internal actors (employees) of the firm quickly understand that for a firm to be competitive, it is necessary to implement both internal and external learning routines. The fact that learning (internal and external learning routines) is significantly related to quality and cost improvements provides further support for the robustness of the knowledge-based view. This is consistent with Zahra et al. (2000) who argue that increases in knowledge strengthen other core competencies and may therefore lead to greater efficiencies. The implementation of internal and external learning routines appear to be a key mechanism by which collaboration is leveraged for the development of quality and cost efficiencies. A firm possessing these knowledge capabilities can shield itself from competitive imitation since such capabilities are developed over time and are deeply embedded in organizational routines, providing the basis for sustained competitive advantage (Barney, 1991; Bharadwaj, 2000).

This study shows that leveraging IT impacts both internal and external learning routines; and by exploiting this knowledge, firms may control the accomplishment of strategic and entrepreneurial objectives in the forms of quality and cost efficiencies. This study also provides strong evidence to suggest that quality efforts generate a greater predisposition for improved costs and customer satisfaction which can lead to the desired effect of increased profitability. Our findings support the view that IT applications affect firm performance by enabling other business processes and capabilities, which in turn may affect firm performance (Mithas et al, 2005, p. 206). The findings are also in support of the dual emphasis that argues that financial benefits accrue to firms from simultaneous cost reductions via efficiencies and revenue enhancements via customer satisfaction improvements (Rust et al., 2002). These findings are important given the widespread belief that successful firms must focus either on quality or low costs (Porter, 1980). Firms following such an approach are less likely to realize anticipated long-term economic returns than firms that also strive to be efficient (Rust et al., 1995). Further analyses indicate that industry group may be important in understanding relationships among the variables under study as implied by Summers (2005).

It is interesting to note the differences found in this study between durable and non-durable industries concerning extent of managerial IT use, learning routines and firm performance, and several explanations are possible. One possibility is that managers use different types of IT systems in durable versus non-durable industries, which vary in terms of how conducive they are for learning routines. A second explanation would be that IT skills tend to be greater among managers in durable industries, thus enabling them to reap greater benefits from using the systems. Thirdly, it could be that firms in durable goods show greater propensity to organize their operations according to horizontal, value chain thinking which can boost the value gained from 
managerial IT use. While there are other possibilities, it is also conceivable that these explanatory factors are related to each other.

However, the limitations of this study should be noted. First, this study was limited to manufacturing firms, although it has been conjectured that the specific contexts of each firm may influence business processes that impact the relationships of the variables included in this study (Yao et al., 2010). Future studies conducted in other than manufacturing settings may also shed light on the generalizability of the theoretical positions developed here. Second, this study operationalizes IT use in terms of the extent to which computer networks are used. Even if there is some recent evidence suggesting that control systems mediate the relationship between IT systems and performance (Kallunki et al., 2011), there is a need for more future studies which control for other types of IT use (e.g., ERP, CREM systems). Third, surveys are not without disadvantages because surveys measure beliefs, which may not always coincide with actions (Graham et al., 2005), and they lack manipulation (Krumwiede, 1998). Therefore, "cause" cannot be inferred from this study. In addition, the survey method, as presented, does limit the use of open-ended questions and face-to-face data gathering and the richness such data might provide. Fourth, this study relied on cross-sectional data, thus, lacks the richer implications that longitudinal data could provide. Collecting longitudinal data can offer richer implications. Fifth, this study has used a limited set of variables in the model to test the consequences of IT use. Also, future studies may incorporate environmental variables and firm characteristics such as market position, rigidities in cost structures (e.g., labor contracts) which affect a firm's strategic options and therefore firm's potential to derive benefits from IT investment. Sixth, even though we used the structural equations method, interpretation of causality between the constructs should be treated with caution. Seventh, we acknowledge that our measurement of the learning routines construct can be considered a limitation of this study. Finally, research might build on this and other studies to provide a more complete understanding and eventually an integrated theory that provides better insights into IT profitability.

Despite the above limitations, this study is important in practice as it contributes significantly to the literature by improving our understanding of how firms can use IT to achieve profitability. The importance of understanding how IT affects firm profitability becomes more critical and can be better appreciated in light of the significant percentage of capital investment that is being allocated to it (Lucas, 1999; Tippins and Sohi, 2003). Firm use of IT has become widespread and organizations continue to search for ways in which to manage information more efficiently. However, there is little evidence of a direct effect of IT on performance (Powell and Dent-Micallef, 1997). Results from this research suggest that managers should not focus on the bottom line alone. Rather, managers should focus on controlling the capabilities and efficiencies associated with IT enhanced processes and structures (e.g., learning routines), since this is where the real benefits can be found (Tippins and Sohi, 2003). In particular, managers need to recognize the role of learning routines and competitive advantage in realizing the value from IT resources. In addition, managers and management accountants implementing multidimensional performance management models, such as balanced scorecard (e.g., Kaplan and Norton, 1992) may benefit from considering IT in that context. Specifically, greater IT use may boost the desired cause/effect-relationships between learning, internal, customer and financial perspectives associated with balanced scorecard. As the resource-based view argues, IT resources offer benefits when they are embedded in specific organizational processes (Barney, 1991).

\section{Appendix A}

\begin{tabular}{|c|c|c|c|c|c|c|c|}
\hline \multicolumn{8}{|l|}{ Extent of managerial IT use (Andersen, 2001) } \\
\hline \multicolumn{8}{|l|}{ Please indicate the extent to which you agree (disagree) with the following: } \\
\hline & & & & & & & All the time \\
\hline $\begin{array}{l}\text { (1) To what extent do managers use electronic mail, etc. to } \\
\text { communicate with different people across the organization? }\end{array}$ & 1 & 2 & 3 & 4 & 5 & 6 & 7 \\
\hline $\begin{array}{l}\text { (2) To what extent do managers access information and data from } \\
\text { other parts of the firm via the computer network? }\end{array}$ & 1 & 2 & 3 & 4 & 5 & 6 & 7 \\
\hline $\begin{array}{l}\text { (3) To what extent do managers use electronic means to exchange } \\
\text { information with manufacturing, engineering, and other functional } \\
\text { areas? }\end{array}$ & 1 & 2 & 3 & 4 & 5 & 6 & 7 \\
\hline
\end{tabular}


Appendix A (continued)

Extent of managerial IT use (Andersen, 2001)

Please indicate the extent to which you agree (disagree) with the following:

\begin{tabular}{llllllll}
\hline & Never & & & All the time \\
\hline $\begin{array}{l}\text { (4) To what extent do managers use the Internet or similar external } \\
\text { data networks to obtain work related information? }\end{array}$ & 1 & 2 & 3 & 4 & 5 & 6 & 7 \\
$\begin{array}{l}\text { (5) To what extent do managers use the Internet or other data interfaces } \\
\text { to communicate with customers, suppliers, and other partners? }\end{array}$ & 1 & 2 & 3 & 4 & 5 & 6 & 7
\end{tabular}

Internal learning routines (Schroeder et al., 2002)

Please indicate the extent to which you agree (disagree) on the following over the last three years:

\begin{tabular}{|c|c|c|c|c|c|c|c|}
\hline \multirow[b]{2}{*}{$\begin{array}{l}\text { (1) Employees are cross-trained so that they can fill in for others if } \\
\text { necessary }\end{array}$} & \multicolumn{6}{|c|}{$\begin{array}{l}\text { Strongly } \\
\text { disagree }\end{array}$} & \multirow{2}{*}{$\begin{array}{l}\begin{array}{l}\text { Strongly } \\
\text { agree }\end{array} \\
7\end{array}$} \\
\hline & 1 & 2 & 3 & 4 & 5 & 6 & \\
\hline (2) Employees receive training to perform multiple tasks & 1 & 2 & 3 & 4 & 5 & 6 & 7 \\
\hline $\begin{array}{l}\text { (3) Management takes all product and process improvement } \\
\text { suggestions seriously }\end{array}$ & 1 & 2 & 3 & 4 & 5 & 6 & 7 \\
\hline (4) Many useful suggestions are implemented & 1 & 2 & 3 & 4 & 5 & 6 & 7 \\
\hline
\end{tabular}

External learning routines (Schroeder et al., 2002)

Please indicate the extent to which you agree (disagree) on the following over the last three years:

\begin{tabular}{|c|c|c|c|c|c|c|c|}
\hline \multirow[b]{2}{*}{ (1) We strive to establish long-term relationships with suppliers } & \multicolumn{6}{|c|}{$\begin{array}{l}\text { Strongly } \\
\text { disagree }\end{array}$} & \multirow{2}{*}{$\begin{array}{l}\begin{array}{l}\text { Strongly } \\
\text { agree }\end{array} \\
7\end{array}$} \\
\hline & 1 & 2 & 3 & 4 & 5 & 6 & \\
\hline $\begin{array}{l}\text { (2) We maintain close communication with suppliers about quality } \\
\text { considerations and design changes }\end{array}$ & 1 & 2 & 3 & 4 & 5 & 6 & 7 \\
\hline (3) Our customers give us feedback on quality and delivery performance & 1 & 2 & 3 & 4 & 5 & 6 & 7 \\
\hline (4) Our customers are actively involved in the product design process & 1 & 2 & 3 & 4 & 5 & 6 & 7 \\
\hline
\end{tabular}

Quality improvement (Ittner et al., 2002)

Please indicate the extent to which your firm has experienced improvement in quality over the last three years

\begin{tabular}{llllllll}
\hline & \multicolumn{3}{l}{$\begin{array}{l}\text { Extremely low } \\
\text { improvement }\end{array}$} & & \multicolumn{3}{c}{$\begin{array}{c}\text { Extremely high } \\
\text { improvement }\end{array}$} \\
\hline (1) Finished product first-pass quality yield in percentage terms & 1 & 2 & 3 & 4 & 5 & 6 & 7 \\
(2) Scrap cost as a percentage of sales & 1 & 2 & 3 & 4 & 5 & 6 & 7 \\
(3) Rework cost as a percentage of sales & 1 & 2 & 3 & 4 & 5 & 6 & 7
\end{tabular}

Cost improvement (Ittner et al., 2002)

Please rate the extent to which your firm has experienced improvement in costs over the last three years

\begin{tabular}{|c|c|c|c|c|c|c|c|}
\hline \multirow[b]{2}{*}{ 1. Direct materials costs } & \multicolumn{6}{|c|}{$\begin{array}{l}\text { Extremely low } \\
\text { improvement }\end{array}$} & \multirow{2}{*}{$\begin{array}{l}\text { Extremely high } \\
\text { improvement }\end{array}$} \\
\hline & 1 & 2 & 3 & 4 & 5 & 6 & \\
\hline 2. Direct labor costs & 1 & 2 & 3 & 4 & 5 & 6 & 7 \\
\hline 3. Overhead costs & 1 & 2 & 3 & 4 & 5 & 6 & 7 \\
\hline 4. Non-manufacturing costs & 1 & 2 & 3 & 4 & 5 & 6 & 7 \\
\hline
\end{tabular}

Customer satisfaction (Sim and Killough, 1998; Ahire and Dreyfus, 2000)

\begin{tabular}{|c|c|c|c|c|c|c|c|}
\hline \multirow[b]{2}{*}{$\begin{array}{l}\text { 1. There has been a steady decline in the number of warranty claims } \\
\text { over the last three years }\end{array}$} & \multicolumn{6}{|c|}{$\begin{array}{l}\text { Very low } \\
\text { decline }\end{array}$} & \multirow{2}{*}{$\begin{array}{l}\text { Very high } \\
\text { decline }\end{array}$} \\
\hline & 1 & 2 & 3 & 4 & 5 & 6 & \\
\hline $\begin{array}{l}\text { 2. There has been a steady decline in the number of product } \\
\text { litigation claims over the last three years }\end{array}$ & 1 & 2 & 3 & 4 & 5 & 6 & 7 \\
\hline $\begin{array}{l}\text { 3. There has been a steady decline in the number of customer } \\
\text { complaints over the last three years }\end{array}$ & 1 & 2 & 3 & 4 & 5 & 6 & 7 \\
\hline
\end{tabular}


Please answer the following:

1. Number of years at this position?

2. Number of years in management?

\section{References}

Adler P, Clark K. Behind the learning curve: a sketch of the learning process. Manag Sci 1991;37(3):267-81.

Ahire SL. TQM age versus quality: an empirical investigation. Prod Inventory Manag J 1996;37(1):18-23.

Ahire SL, Dreyfus P. The impact of design management and process management on quality: an empirical investigation. J Oper Manag 2000;18(5):549-75.

Andersen TJ. Information technology, strategic decision making approaches and organizational performance in different industrial settings. J Strateg Inf Syst 2001;10:101-19.

Anderson JC, Gerbing DW. Structural equation modeling in practice: a review and recommended two-step approach. Psychol Bull 1988;103:411-23.

Anderson EW, Fornell C, Lehmann DR. Customer satisfaction, market share, and profitability: findings from Sweden. J Mark 1994;58(3):53-66.

Armstrong SJ, Overton TS. Estimating nonresponse bias in mail surveys. J Mark Res 1977;14:396-402.

Atkinson AA, Banker RD, Kaplan RS, Young SM. Management accounting. Upper Saddle River, NJ: Prentice Hall; 2001.

Babich P. Customer satisfaction: how good is good enough? Qual Program 1992;25(12):65-7.

Banker RD, Kauffman RJ. Strategic contributions of information technology: an empirical study of ATM networks. Proceedings of the 9th international conference on information systems, Minneapolis, MN; 1988. p. 141-50.

Barney JB. Firm resources and sustained competitive advantage. J Manag 1991;17(1):99-120.

Barua A, Mukhopadhyay T. Information technology and business performance: past, present, and future. In: Zmud RW, editor. Framing the domains of IT management. Cincinnati (OH): Pinnaflex Educational Resources; 2000.

Beath CM, Goodhue DL, Ross JR. Partnering for business value: the shared management of IS infrastructure. In: DeGross JI, Huff SL, Munro MC, editors. Proceedings of the fifteenth international conference on information systems, Vancouver, British Columbia; 1994. p. 459-60.

Bentler PM. Multivariate analysis with latent variables: causal modeling. Annu Rev Psychol 1980;3:419-56.

Bentler PM, Bonnet DG. Significance tests and goodness-of-fit in the analysis of covariance structures. Psychol Bull 1980;88:588-606.

Berman SL, Wicks AC, Kotha S, Jones TM. Does stakeholder orientation matter? The relationship between stakeholder management models and firm financial performance. Acad Manage J 1999;42:488-508.

Bharadwaj A. A resource-based perspective on information technology capability and firm performance: an empirical investigation. MIS Q 2000;24:169-96.

Bhattacherjee A, Premkumar G. Understanding changes in belief and attitude toward information technology usage: a theoretical model and longitudinal test. MIS Q 2004;28(2):229-54.

Bollen KA. Structural equations with latent variables. New York, NY: Wiley; 1989.

Bunderson JS, Sutcliffe KM. Management team learning orientation and business unit performance. J Appl Psychol 2003;88:552-60.

Buzzell RD, Gale BT. Das PIMS-programm. Gabler Verlag: Wiesbaden; 1989.

Choi TY, Eboch K. The TQM paradox: relations among TQM practices, plant performance, and customer satisfaction. J Oper Manag 1998;17:59-75.

Clemons EK, Row MC. Sustaining IT advantage: the role of structural differences. MIS Q 1991;15(3):275-92.

Cohen W, Levinthal D. Absorptive capacity: a new perspective on learning and innovation. Adm Sci Q 1990;35:128-52.

Conner K, Prahalad CK. A resource-based theory of the firm: knowledge versus opportunism. Organ Sci 1996;7(5):477-501.

Cronbach LJ. Coefficient alpha and the internal structure of tests. Psychometrika 1951;16:297-334.

Crosby PB. Quality is free: the art of making quality certain, vol. 94. New York: McGraw-Hill; 1979.

Crosby PB. Quality Without Tears; 1984.

Crosby PB. Quality is still free. New York: McGraw Hill; 1996.

D'Souza DE, Williams FP. Toward a taxomy of manufacturing flexibility dimensions. J Oper Manag 2000;18:577-93.

Dawson P, Patrickson M. Total quality management in Australian banking industry. Int J Qual Sci Reliab Manag 1991;8(5):66-76.

Day GS. The capabilities of market-driven organizations. Marketing Science Institute report no. 93-123; 1993.

Day GS. The capabilities of market-driven organizations. J Mark 1994;58:37-51.

Dechow N, Granlund M, Mouritsen J. Interactions between modern information technology and management control. In: Hopper T, Northcott D, Scapens R, editors. Issues in management accounting. Essex, UK: Pearson Education Limited; 2007. p. 45-64.

Dedrick J, Gurbaxani V, Kraemer KL. Information technology and economic performance: a critical review of the empirical evidence. ACM Comput Surv 2003;35(1):1-28.

Deming WE. Out of the crisis. Cambridge, MA: MIT Center for Advanced Engineering Study; 1986.

Dutton JM, Freedman RD. External environment and internal strategies: calculating, experimenting and imitating in organizations. In: Lamb R, Shrivastava P, editors. Advances in strategic management, 3. Greenwich, CT: JAI Press; 1985. p. 39-67.

Fairfield PM, Yohn TL. Using asset turnover and profit margin to forecast changes in profitability. Rev Account Stud 2001;6(4): 371-85.

Fawcett SE, Wallin C, Allred C, Fawcett AM, Magnana GM. Information technology as an enabler of supply chain collaboration: a dynamic-capabilities perspective. J Supply Chain Manag 2011;47:38-58.

Floyd SW, Woolridge B. Path analysis of the relationship between competitive strategy, information technology, and financial performance. J Manag Inf Syst 1990;7(1):47-64.

Fornell C. A national customer satisfaction: the Swedish experience. J Mark 1992;56(1):6-21.

Fornell C, Larcker DF. Evaluating structural equation models with unobservable variables and measurement error. J Mark Res $1981 ; 18: 39-50$. 
Freeman E, York J, Stewart L. Environment, ethics, and business. Charlottesville, Virginia: Business Roundtable Institute for Corporate Ethics; 2008.

Garvin DA. Building a learning organisation. Harv Bus Rev 1993:78-91. [July-August].

George S, Weimerskirch A. Total quality management: strategies and techniques proven at today's most successful companies. New York: Wiley; 1994.

Gibson C, Vermeulen F. A healthy divide: subgroups as a stimulus for team learning behavior. Adm Sci Q 2003;48(2):202-39.

Gopal A, Koka BR. Determinants of service quality in offshore software outsourcing. Information systems outsourcing: enduring themes, new perspectives and global challenges. 3rd ed. 2008.

Graham JR, Harvey C, Rajgopal S. The economic implications of corporate financial reporting. J Account Econ 2005;40(1-3):3-17.

Hair Jr JF, Anderson RE, Tatham RL, Black WC. Multivariate data analysis. 4th ed. New Jersey: Prentice-Hall; 1995.

Hall WK. Survival strategies in a hostile environment. Harv Bus Rev 1980;58(5):75-85.

Hambrick DC. Environmental scanning and organizational strategy. Strateg Manag J 1982;3:159-74.

Hambrick DC. High profit strategies in mature capital goods industries: a contingency approach. Acad Manage J 1983;26(4):687-707.

Handfield R. Effects of concurrent engineering on make-to-order products. IEEE Trans Eng Manag 1994;41(4):1-11.

Hardie N. The effects of quality on business performance. Qual Manag J 1998;3:65-81.

Hauser JR, Simester DL, Wernerfelt B. Customer satisfaction incentives. Mark Sci 1994:327-50. [Fall].

Hayduk LA. Structural equation modeling with LISREL: essentials and advances. Baltimore, MD: John Hopkins Press; 1987.

Hayes RH, Wheelwright SC, Clark KB. Dynamic manufacturing: creating the learning organization. New York: The Free Press; 1988.

Hitt LM, Brynjolfsson E. Productivity, business profitability, and consumer surplus: three different measures of information technology value. MIS Q 1996;20(2):121-42.

Huang YM, Chen JN, Kuo YH, Jeng YL. An intelligent human-expert forum system based on fuzzy information retrieval technique. Expert Syst Appl 2008;34(1):446-58.

Huber G. Organizational information systems: determinants of their performance and behavior. Manage Sci 1982;28(2):138-55.

Hunt SD, Morgan RM. The comparative advantage theory of competition. J Mark 1995;59:1-15.

Ittner CD, Lanen WN, Larcker DF. The association between activity-based costing and manufacturing performance. J Account Res 2002;40(3):711-26.

Jacobs FA, Latham CK, Lee C. The relationship of customer satisfaction to strategic decisions. J Managerial Issues 1998;10:165-82.

Jacobs FA, Johnston W, Kotchetova N. Customer profitability: prospective vs. retrospective approaches in a business-to-business setting. Ind Mark Manag 2001;30(4):353-63.

James LR, Mulaik SA, Brett JM. Causal analysis: assumptions, models, and data. Beverly Hills, CA: Sage; 1982.

Jelinek M. Institutionalizing innovations, a study of organizational learning systems. New York: Praeger; 1979.

Joreskog KG, Sorbom D. LISREL 8: user's reference guide. Chicago, IL: Scientific Software; 1993.

Juran JM. Juran on quality improvement. New York, NY: Juran Institute; 1982.

Kallunki JP, Laitinen EK, Silvola H. Impact of enterprise resource planning systems on management control systems and firm performance. Int J Account Inf Syst 2011;12:20-39. [March].

Kaplan RS, Norton DP. The balanced scorecard: measures that drive performance. Harv Bus Rev 1992:71-9. [Jan/Feb].

Kessler EH, Bierly PE, Gopalakrishnan S. Internal vs. external learning in new product development: effects on speed, costs and competitive advantage. R\&D Manag 2000;30(3):213-23.

Kettinger W, Grover V, Guha S, Segars A. Strategic information systems revisited: a study in sustainability and performance. MIS Q $1994 ; 18(1): 31-58$

Kinney M, Wempe W. Further evidence on the extent and origins of JIT's profitability effects. Account Rev 2002;77(1):203-25.

Kochan TA, Useem M, editors. Transforming organizations. New York: Oxford University Press; 1992.

Kohli AK, Jaworski BJ. Market orientation: the construct, research propositions, and managerial implications. J Mark 1990;54:1-18.

Koufteros XA. Testing a model of pull production: a paradigm for manufacturing research using structural equation modeling. J Oper Manag 1999;17(4):467-88.

Koufteros XA, Vonderembse M, Jayaram J. Internal and external integration for product development: the contingency effects of uncertainty, equivocality, and platform strategy. Decis Sci 2005;36(1):97-133.

Krumwiede KR. The implementation stages of activity-based costing and the impact of contextual and organizational factors. J Manag Account Res 1998;10:239-77.

Lado AA, Zhang MJ. Expert systems, knowledge development and utilization, and sustained competitive advantage: a resource-based model. J Manag 1998;24(4):489-509.

Lambert Rob, Peppard Joe. Information technology and new organizational forms: destination but no road map? J Strateg Inf Syst 1993;2(3):180-205.

Lane PJ, Koka BR, Pathak S. The reification of absorptive capacity: a critical review and rejuvenation of the construct. Acad Manage Rev 2006;31:833-63.

Lau AKW, Yam RCM, Tang EPY. Supply chain integration and product modularity: an empirical study of product performance for selected Hong Kong manufacturing industries. Int J Oper Prod Manag 2010;30(1):20-56.

Lee JF, Wu CS, Wu SH. The strategic implications of alliances and networks in the process of Taiwanese industrial development. Taipei: Mimeo, National Chengchi University; 1996.

Levitt B, March JG. Organizational learning. Annu Rev Sociol 1988;14:319-38.

Lin BW. Technology transfer as technological learning: a source of competitive advantage for firms with limited R\&D resources. R\&D Manag 2003;33(3):327-41.

Little S, Quintas P, Ray T. Managing knowledge. London: SAGE Publications Ltd; 2002.

Lucas H. Information technology and the productivity paradox. New York: Oxford University Press; 1999.

Lynch RL, Cross KF. Measure up! Yardsticks for continuous improvements. Oxford: Blackwell; 1991.

Mahmood M, Soon SKA. Comprehensive model for measuring the potential impact of information technology on organizational strategic variables. Decis Sci 1991;22(4):869-97.

Maiga AS, Jacobs FA. Antecedents and consequences of quality performance. Behav Res Account 2005;17:111-31.

Makadok R. Toward a synthesis of the resource-based and dynamic-capability views of rent creation. Strateg Manag J 2001;22:387-401.

Maruyana GM. Basics of structural equation modeling. London: Sage Publications, Inc.; 1998. 
Mata FJ, Fuerst WL, Barney JB. Information technology and sustained competitive advantage: a resource based analysis. Manag Inf Syst Q 1995:487-505.

Medsker GJ, Williams LJ, Holahan PJ. A review of current practice for evaluating causal models in organizational behavior and human resources management research. J Manag 1994;20:439-64.

Meso P, Smith R. A resource-based view of organizational knowledge management systems. J Knowl Manag 2000;4(3):224-34.

Meyer C. Fast cycle time: how to align purpose, strategy and structure for speed. New York, NY: Free Press; 1993.

Miller D, Friesen PH. Porter's (1980) generic strategies and performance: an empirical examination with American data: part 1: testing Porter. Org Stud 1986;7(1):37-55.

Mithas S, Krishnan MS, Fornell C. Why do customer relationship management applications affect customer satisfaction? J Mark 2005;69(4):201-9.

Mohrman SA, Mohrman Jr AM. Organizational change and learning. In: Galbraith JR, Lawler III EE, editors. Organizing for the future: the new logic for managing complex organizations. San Francisco, CA: Jossey-Bass Publishers; 1993. p. 87-108.

Nelson RR, Winter SG. An evolutionary theory of economic change. Cambridge, Mass.: Harvard University Press; 1982

NIST, Gaithersburg. National Institute of Standards and Technology: Gaithersburg. No. 20899; 2003 [Mar].

Nunnally J. Psychometric theory. New York: McGraw-Hill; 1978.

Pedler M, Burgoyne J, Boydell T. The learning company: a strategy for sustainable development. Maidenhead: McGraw-Hill; 1997.

Pijpers GGM, Bemelmans TMA, Heemstra FJ, Monfort KAGM. Senior executives use of information technology. Inf Softw Technol 2001;43:959-71.

Pisano GP. Knowledge, integration, and the locus of learning: an empirical analysis of process development. Strateg Manag J 1994;15:85-100. [Winter Special Issue].

Porter ME. Competitive strategy: techniques for analyzing industries and competitors. New York: The Free Press; 1980.

Porter ME. Competitive Advantage; 1985 [New York].

Porter ME, Millar V. How information technology gives you competitive advantage. Harv Bus Rev 1985;63(4):149-60.

Powell C, Dent-Micallef A. Information technology as competitive advantage: the role of human, business, and technology resources. Strateg Manag J 1997;18(5):375-405.

Quinn Mills D, Friesen B. The learning organization. Eur Manag J 1992;10(2):146-56.

Rackoff N, Wiseman C, Ullrich WA. Information systems for competitive advantage: implementation of a planning process. MIS Q 1985;9(4):112-24

Real JC, Leal A, Roldan JL. Information technology as a determinant of organizational learning and technological distinctive competencies. Ind Mark Manag 2006;35(4):505-21.

Rust RT, Zahorik AJ. Customer satisfaction, customer retention, and market share. J Retailing 1993;69:193-215.

Rust RT, Zahorik AJ, Keiningham TL. Return on quality (ROQ): making service quality financially accountable. J Mark 1995;59:58-70.

Rust RT, Moorman C, Dickson PR. Getting return on quality: revenue expansion, cost reduction, or both? J Mark 2002;66:7-14.

Sabherwal R, King W. Towards a theory of the strategic use of information resources: an inductive approach. Inf Manage 1991;20(3): 191-212.

Sambamurthy V, Zmud RW. IT management competency assessment: a tool for creating business value through IT. Working paper. Financial Executives Research Foundation; 1994.

Sambamurthy V, Bharadwaj A, Grover V. Shaping agility through digital options: reconceptualizing the role of information technology in contemporary firms. MIS Q 2003;27(2):237-63.

Schroeder R, Bates K, Junttila M. A resource-based view of manufacturing strategy and the relationship to manufacturing performance. Strateg Manag J 2002;23(2):105-17.

Senge PM. The fifth discipline: the art and practice of the learning organization. New York: Doubleday/Currency; 1990a.

Senge PM. The leaders' new work: building learning organizations. Sloan Manage Rev 1990b:7-23. [Fall].

Senge P. The learning organization made plain. Training Dev 1991;45(10):37-44.

Shapiro R, Heskett J. Logistics strategy: cases and concepts. St Paul, MN: West Publishing Co.; 1985.

Shrivastava P. A typology of organizational learning systems. J Manag Stud 1983;20(2):7-28.

Shrout PE, Fleiss JL. Intraclass correlations: uses in assessing reliability. Psychol Bull 1979;86:420-8.

Siegel S. Nonparametric statistics for the behavioral sciences. New York: McGraw-Hill Co.; 1956.

Sim KL, Killough KL. The performance effects of complementaries between manufacturing practices and management accounting systems. J Manag Account Res 1998;10:325-46.

Simonin BL. Ambiguity and the process of knowledge transfer in strategic alliances. Strateg Manag J 1999;20:595-623.

Slater SF, Narver JC. Does competitive environment moderate the market orientation-performance relationship? J Mark 1994;58:46-55.

Slater SF, Narver JC. Market orientation and the learning organization. J Mark 1995;59:63-74.

Slaughter SA, Harter DE, Krishnan MS. Evaluating the cost of software quality. Commun ACM 1998;41:67.

Smith K, Vasudevan S, Tanniru M. Organizational learning and resource-based theory: an integrative model. J Organ Chang Manag 1996;9(6):41-53.

Spanos Y, Zaralis G, Lioukas S. Strategy and industry effects on profitability: evidence from Greece. Strateg Manag J 2004;25: 139-65.

Stata R. Organizational learning - the key to management innovation. Sloan Manage Rev 1989:63-73. [Spring].

Steiger JH, Lind JM. Statistically based tests for the number of common factors. Paper presented at the annual meeting of the Psychometric Society, Iowa City, IA; 1980.

Storey DJ. Understanding the small business sector. London: Routledge; 1994.

Summers P. What caused the great moderation? Some cross-country evidence. Econ Rev - Fed Res Bank Kan 2005;95(3):6-32.

Tan KC. A framework of supply chain management literature. Eur J Purch Supply Chain Manag 2001;7:39-48.

Teece DJ. Strategies for managing knowledge assets: the role of firm structure and industrial context. Long Range Plann 2000;33: 35-54.

Teo TSH, Ranganathan C. Leveraging IT resources and capabilities at the housing and development board. J Strateg Inf Syst 2003;12: 229-49.

Tiger L, Calantone RJ. The impact of market knowledge competence on the new product advantage: conceptualization and empirical examination. J Mark 1998;62:13-29. 
Tippins MJ, Sohi RS. IT competency and firm performance: is organizational learning a missing link? Strateg Manag J 2003;24: 745-61.

Tuominen M, Moller K, Rajala A. Marketing capability: a nexus of learning-based resources and a prerequisite for market orientation. Proceedings of the annual conference of the European Marketing Academy; 1997. p. 1220-40.

Voss C, Blackmon K. Total quality management and ISO 9000: a European study. London: Centre for Operations Management, London Business School; 1994.

Wolak R, Kalafatis S, Harris P. An investigation into four characteristics of services. J Empir Gen Mark Sci 1998;3:22-41.

Wong JK-K. Are the learning styles of Asian international students culturally or contextually based? Int Educ J 2004;4(4):154-66.

Yao LJ, Liu C, Chan SH. The influence of firm specific context on realizing information technology business value in manufacturing industry. Int J Account Inf Syst 2010;11(4):353-62.

Yi Y. A critical review of consumer satisfaction. In: Zeithaml V, editor. Review of marketing. Chicago, IL: American Marketing Association; 1990. p. 68-123.

Young SM, Selto FH. Explaining cross-sectional workgroup performance differences in a JIT facility: a critical appraisal of a field-based study. J Manag Account Res 1993;5:300-26.

Zahra SA, Covin JG. Business strategy, technology policy and firm performance. Strateg Manag J 1993;14:451-78.

Zahra SA, Ireland RD, Hitt MA. International expansion by new venture firms: international diversity, mode of market entry, technological learning, and performance. Acad Manage J 2000;43(5):925-50. 